\title{
Review of the Early Cretaceous erymid lobsters (Crustacea: Decapoda) from the Western Tethys
}

\section{Révision des Érymides (Crustacea : Decapoda) du Crétacé inférieur de la Téthys occidentale}

\author{
Julien Devillez \\ Muséum national d'Histoire naturelle, Paris \\ Centre de Recherche sur la Paléobiodiversité et les Paléoenvironnements (CR2P, UMR 7207), Sorbonne \\ Universités, MNHN, UPMC, CNRS, 57 rue Cuvier F-75005 Paris (France) \\ jdeville@edu.mnhn.fr
}

Sylvain Charbonnier

Muséum national d'Histoire naturelle, Paris

Centre de Recherche sur la Paléobiodiversité et les Paléoenvironnements (CR2P, UMR 7207), Sorbonne Universités, MNHN, UPMC, CNRS, 57 rue Cuvier F-75005 Paris (France)

scharbonnier@mnhn.fr

\section{Matúš Hyžný}

Department of Geology and Palaeontology, Faculty of Natural Sciences, Comenius University, Mlynská dolina G1, 84215 Bratislava (Slovakia); Geologisch-paläontologische Abteilung, Naturhistorisches Museum Wien, Burgring 7, 1010 Vienna (Austria)

hyzny.matus@gmail.com

Lucien Leroy

Hameau de Taloire F-04120 Castellane (France)

lucien.leroy@orange.fr

RÉSUMÉ

Les érymides (Crustacea, Decapoda, Erymidae) sont relativement courants et abondants dans les formations jurassiques ( $\mathrm{ca} 70$ espèces) mais sont beaucoup moins courants dans le Crétacé inférieur où une vingtaine d'espèces sont recensées en Europe, en Amérique du Nord, en Amérique du Sud, en Australie, en Antarctique, au Japon et à Madagascar. Une révision des douze espèces d'érymides du Crétacé inférieur d'Europe (France, Royaume-Uni) est ici présentée. Basés sur de nouvelles observations, les concepts de plusieurs genres d'érymides sont actualisés et de nouvelles diagnoses sont proposées pour Eryma Meyer, 1840, Enoploclytia M'Coy, 1849, Palaeastacus Bell, 1850, Pustulina Quenstedt, 1857, et Stenodactylina Beurlen, 1928, incluant le tracé des sillons de la carapace, la première paire de péréiopodes et aussi une nouvelle structure -la zone post-orbitaire- située à l'avant de la région céphalique. Le nouveau genre Tethysastacus est établi avec Tethysastacus tithonius n. comb. (Valanginien, France) comme espèce-type. Cinq nouvelles espèces sont aussi décrites : Eryma vocontii n. sp. (Albien, France), Enoploclytia augustobonae n. sp. (Barrémien, France), Enoploclytia gigantea n. sp. (Albien, Texas), Pustulina occitana n. sp. (Berriasien, France), et Pustulina colossea n. sp. (Hauterivien, France).

MOTS CLÉS 
Crustacea, Erymidae, Europe occidentale, France, homard, Mésozoïque, Royaume-Uni.

\section{ABSTRACT}

Erymid lobsters (Crustacea, Decapoda, Erymidae) are relatively common and abundant in Jurassic rocks ( $c$ a 70 species) but are far less common in the Early Cretaceous with about 20 species only listed in Europe, North America, South America, Australia, Antarctic, Japan, and Madagascar. A study of the twelve species of erymid lobsters from the Early Cretaceous of Europe (France, United Kingdom) is here presented. Based on new observations, the concepts of some erymid genera are updated and new diagnoses are proposed for Eryma Meyer, 1840, Enoploclytia M'Coy, 1849, Palaeastacus Bell, 1850, Pustulina Quenstedt, 1857, and Stenodactylina Beurlen, 1928, including carapace groove pattern, first pereiopods and also a new structure -the post-orbital area- located in front of the cephalic region. The new genus Tethysastacus is erected with Tethysastacus tithonius n. comb. (Valanginian, France) as type species. Five new species are described: Eryma vocontii n. sp. (Albian, France), Enoploclytia augustobonae n. sp. (Barremian, France), Enoploclytia gigantea n. sp. (Albian, Texas), Pustulina occitana n. sp. (Berriasian, France), and Pustulina colossea n. sp. (Hauterivian, France).

KEY WORDS

Crustacea, Erymidae, lobster, Mesozoic, France, United Kingdom, Western Europe.

\section{INTRODUCTION}

Erymid lobsters are typical Mesozoic crustaceans exhibiting a worldwide distribution with occurrences in Europe (e.g., Mantell 1833; Bell 1850, 1863; Oppel 1861, 1862; Lahusen 1894; Van Straelen 1925; Beurlen 1928; Glaessner 1931; Bachmayer 1959; Förster \& Rieber 1982; Garassino 1996; Jagt \& Fraaije 2002; Garassino \& Krobicki 2002; Bravi et al. 2014), in the Middle East (Roger 1946; Förster \& SeyedEmani 1982; Garassino 1994; Charbonnier et al. in press), in North Africa (Secrétan 1984), in Western Africa (Joleaud \& Hsu 1935), in Madagascar (Secrétan 1964; Charbonnier et al. 2012a), in North America (Rathbun 1923, 1926; Stenzel 1945; Feldmann \& McPherson 1980; Schweitzer \& Feldmann 2001; Feldmann \& Titus 2006; Feldmann \& Haggart 2007), in Latin America (Aguirre Urreta \& Ramos 1981; Aguirre Urreta 1982, 1989; Vega et al. 2013), in Australia (Woodward 1877; Etheridge Jr. 1914; Woods 1957), in Antarctic (Taylor 1979; Aguirre Urreta 1989), and in Japan (Karasawa et al. 2008).

Despite their wide distribution, fossils of erymid lobsters remain sparse and fragmentary. This is a consequence of the low fossilization potential of decapod crustaceans (scavenging, decortication, disarticulation, carapace fragmentation) and of collection and reporting biases (Plotnick 1986; Bishop 1986; Plotnick et al. 1988; Tshudy et al. 1989; Müller et al. 2000; Stempien 2005; Mutel et al. 2008; Krause et al. 
2011). So about twenty erymid species, mainly supported by a unique or a few number of fragments, are currently reported in the Early Cretaceous.

The carapace groove pattern of these decapod crustaceans is the main feature used for genera and species distinction (Van Straelen 1925; Förster 1966; Glaessner 1969). However, the diagnoses of erymid genera are not still consistent with each other, in particular for Eryma Meyer, 1840 and Palaeastacus Bell, 1850, both including the greatest number of species (Hyžný et al. 2015). The present contribution aims to give a new look on Early Cretaceous erymid faunas around the world, especially on European taxa which benefits from new diagnoses and descriptions. This review is also an occasion to clarify some generic concepts in Erymidae based on carapace groove pattern, first pereiopods, and carapace regions (Fig. 1).

\section{MATERIAL AND METHODS}

The entire studied material includes 160 specimens (Table 1). They were mostly studied using a CETI Belgium MEDO binocular microscope. Line drawings were prepared by the first author. Most of the studied specimens consist of isolated carapaces and first chelipeds. Most of the European species come from southeastern France and were collected from the Early Cretaceous deposits of the South-East Basin (Fig. 2), including the Vocontian Basin and its peripheral platforms (Arnaud-Vanneau et al. 1982; Friès \& Parize 2003), which was part of the western margin of the Tethys Ocean (Savostin et al. 1986; Masse et al. 1993).

\section{INSTITUTIONAL ABBREVIATIONS}

$\begin{array}{ll}\text { BM } & \begin{array}{l}\text { Booth Museum of Natural History, Brighton (United Kingdom). } \\ \text { MHNG }\end{array} \\ \text { MNHN.F } & \begin{array}{l}\text { Muséum d'Histoire naturelle de Genève, département de géologie et paléontologie } \\ \text { (Switzerland). }\end{array} \\ \text { MHNC } & \text { Muséum d'Histoire naturelle, Chambéry (France). } \\ \text { NHMUK } & \text { Natural History Museum, London (United Kingdom). } \\ \text { OSUG } & \text { Observatoire des Sciences de l'Univers de Grenoble (France). } \\ \text { SM } & \text { Sedgwick Museum of Earth Sciences, Cambridge (United Kingdom). }\end{array}$

\section{ANATOMICAL TERMINOLOGY AND ABBREVIATIONS}

Post-orbital area. - Taylor (1979) observed firstly in the cephalic region of Palaeastacus foersteri Taylor, 1979, a complex structure behind the ocular incision (Fig. 3A). He briefly described it: "a deeply incised and almost vertical groove parallel to the orbital margin probably represents the forward extension of the antennal groove". We propose to name this complex structure "post-orbital area" and we provide a detailed description. The post-orbital area is a slightly bulged area limited by the 
carinated anterior margin of cephalic region and a S-shaped anterior groove joined ventrally to antennal groove (Fig. 3B).

P1 chelipeds. - In extant representatives of lobsters, P1 chelae are laterally inclined, so the palms are almost in the horizontal plan. Thus, in this configuration the occlusal openings are in the horizontal plane. In this paper we follow this natural configuration for the description of the chelae (Fig. 3C): the palms are the widest sides and correspond to the ventral and dorsal surfaces of the chelae; similarly, the longitudinal margins correspond to inner and outer margins with dactylus located on the inner margin and index on the outer margin. Most of the time, the fingers are curved downside in lateral view.

\title{
Abbreviations.
}

CL Carapace length excluding rostrum.

$\mathrm{CH}$ Carapace height.

$\omega \quad$ Attachment site of mandibular muscle.

$\chi \quad$ Attachment site of adductor testis muscle.

P1-P5 Pereiopods 1 to 5 .

s1-s3 Somites 1 to 3.

\section{SYSTEMATIC PALAEONTOLOGY}

\author{
MALACOSTRACA Latreille, 1802 \\ DECAPODA Latreille, 1802 \\ ERYMIDA sensu Schram \& Dixon, 2004 \\ Superfamily ERYMOIDEA Van Straelen, 1925 \\ Family ERYMIDAE Van Straelen, 1925
}

PRELIMINARY REMARK. - The phylogenetic position of Erymidae varies throughout the literature. For a long time the family has been included within the Astacidea Latreille, 1802 (Van Straelen 1925; Glaessner 1969; Aguirre-Urreta 1989; Schweigert et al. 2000; Garassino \& Krobicki 2002; Crônier \& Courville 2004; Garassino \& Schweigert 2006; Feldmann \& Titus 2006; Schweigert 2013; Charbonnier et al. 2013), whereas some more recent contributions recognised the family to belong to Glypheidea Zittel, 1885 (De Grave et al. 2009; Schweitzer et al. 2010; Wahle et al. 2012; Karasawa et al. 2013; Feldmann et al. 2015). Recent phylogenetic analysis by Charbonnier et al. (2015) questioned the assignment of Erymidae to Glypheidea. Following Hyžný et al. (2015), we consider the systematic position of the Erymidae as uncertain and do not list the taxonomic rank beyond the superfamily. Following Schram \& Dixon (2004), we only include the Erymidae in a separate clade named Erymida. 
Eryma Meyer, 1840a: 587.

Klytia Meyer, 1840b: 19.

Eryma - Oppel 1862: 20. — Zittel 1885: 693. — Van Straelen 1925: 233. — Rathbun 1926: 127. — Secrétan 1964: 61. - Förster 1966: 88. — Glaessner 1969: 455. — Aguirre Urreta \& Ramos 1981: 609. — Secrétan 1984: 516. — Aguirre Urreta 1989: 513. — Crônier \& Courville 2004: 1004. — Feldmann \& Titus 2006: 63. — Feldmann \& Haggart 2007: 1792. — Hyžný et al. 2015: 375. — Feldmann et al. 2015: 1.

TYPE SPECIES. - Macrourites modestiformis Schlotheim, 1822, by subsequent designation of Glaessner (1929).

EMENDED DiAgNOSIS. - Fusiform intercalated plate; deep cervical groove, joined to dorsal margin and to antennal groove; short gastro-orbital groove originating as a slight median inflexion of cervical groove; postcervical and branchiocardiac grooves subparallel; postcervical groove joined medially to branchiocardiac groove (with a short ventral extension); branchiocardiac groove strongly inclined, joined to hepatic groove; concavo-convex hepatic groove, joined to cervical groove; inferior groove convex posteriorly, joined to hepatic groove; marked $\omega$ bulge; cephalic region with two divergent rows of tubercles: orbital row with strong distal spine and antennal row with strong distal antennal spine; chelate P1-P3; P1 chelipeds without prominent spines and with homogeneous ornamentation; P1 propodus dorso-ventrally compressed with narrow inner and outer margins; P1 with narrow dactylar bulge; fingers longer than P1 propodus, equal in length, narrowing gradually to distal extremity; index wider than dactylus.

COMMENTS. - Some species show short P1 fingers such as Eryma modestiforme or E. punctatum Oppel, 1861, and other species show long P1 fingers such as E. bedeltum (Quenstedt, 1857) or E. ventrosum (Meyer, 1840). Following Hyžný et al. (2015), we distinguish two forms chelae. Form I (Fig. 1B) has a short rectangular propodus with straight fingers slightly longer than the propodus; form II (Fig. 1C) has an elongate subrectangular or trapezoidal propodus with long fingers which are usually curved inward.

\section{Eryma vocontii $\mathrm{n}$. sp.}

(Fig. 4A-F)

ETYMOLOGY. - The specific epithet refers to the Voconces, a prealpine federation of Gaul people.

TYPE MATERIAL. - Holotype MNHN.F.A57457 (carapace); paratype MNHN.F.A57458 (P1 chela) (Clément coll.). 
Type LoCAlity. - Rosans, Hautes-Alpes department, Provence-Alpes-Côte d'Azur region, southeastern France.

TyPe AGE. - Albian, Early Cretaceous.

DESCRIPTION. - Subcylindrical carapace (holotype: $\mathrm{CL}=23 \mathrm{~mm}, \mathrm{CH}=10 \mathrm{~mm}$ ); rostrum not preserved; subvertical cervical groove, dorsally wide and deep, strongly narrowing under gastro-orbital groove, joined to antennal groove; cephalic region with oblique orbital row of tubercles (antennal row poorly preserved); narrow, curved antennal groove; short, wide gastro-orbital groove, originating as a slight median inflexion of cervical groove; straight, wide and deep postcervical groove, joined to dorsal margin and joined medially to branchiocardiac groove, extended with a short ventral extension; straight, strongly inclined branchiocardiac groove with narrow dorsal part, joined to dorsal margin and to hepatic groove; narrow and shallow hepatic groove, concavo-convex; strongly raised $\omega$ and $\chi$ bulges; sub-rectangular $\chi$ bulge dorsally limited by shallow depression running between hepatic and branchiocardiac grooves; rounded $\omega$ bulge; inferior groove poorly preserved; carapace uniformly covered with fine tubercles preceded by crescent-shaped pits (pits deeper in branchial region); P1 chela with compressed trapezoidal propodus; dorsal surface of P1 palm with median longitudinal bulge surrounded by two longitudinal depressions parallel to lateral margins; P1 palm with narrow dactylar bulge, posteriorly delimited by a shallow groove; long, straight fingers, gradually narrowing to distal extremity; index wider than dactylus; dactylus with small basal depression; occlusal margins slightly denticulate; propodus covered with fine tubercles; fingers covered with punctations. P1 belongs to claw form II.

Discussion. - Paratype MNHN.F.A57458 (Fig. 4E, F) corresponds to an isolated right P1 chela collected in the same bed than the carapace MNHN.F.A57457 (Fig. 4A-D). Based on this report, we suggest that the association carapace-chela comes from the same species and we include the chela in the specific description.

Eryma vocontii n. sp. is assigned to Eryma Meyer, 1840 based on its typical carapace groove pattern and its tuberculate orbital row in cephalic region. Eryma vocontii n. sp. differs from the three other Early Cretaceous species, Eryma glaessneri (Van Straelen, 1936), Eryma nippon Karasawa et al., 2008, and Eryma sulcatum Harbort, 1905 by its carapace groove pattern with (1) subvertical cervical groove (strongly inclined in the three other species), (2) straight, deep postcervical groove, slightly inclined and joined to dorsal margin (sinuous and strongly inclined in E. glaessneri; shallow, slightly convex forward and not joined to dorsal margin in E. sulcatum), (3) straight, shallow and strongly inflected branchiocardiac groove (sinuous in E. glaessneri; slightly inflected in E. sulcatum), and (4) short gastro-orbital groove (long in E. glaessneri). Moreover, E. glaessneri exhibits a relatively massive carapace with inflated branchial region (not inflated in Eryma vocontii n. sp.) and a flat attatchment site of adductor testis muscle (inflated in Eryma vocontii n. sp.), and Eryma sulcatum exhibits a post-orbital area (absent in Eryma vocontii n. sp.). Eryma nippon 
has a circular $\chi$ bulge while it is sub-rectangular in Eryma vocontii n. sp. Eryma vocontii n. sp. has a carapace with uniform fine ornamentation whereas the carapaces of E. glaessneri and E. sulcatum show heterogeneous ornamentation (coarse tubercles in cardiac and cephalic regions in E. glaessneri; smaller and more dense ornamentation in branchial region with regard to the rest of carapace and row of coarse tubercles parallel to intercalated plate in E. sulcatum). E. nippon has a homogeneous ornamentation but it is made of coarse tubercles (small tubercles in Eryma vocontii n. sp.).

Other Cretaceous Eryma species were described from North America (Eryma americanum Rathbun, 1923, Eryma flectum Rathbun, 1926, and Eryma stantoni Rathbun, 1935) and from Lebanon (Eryma cretaceum Roger, 1946). After careful examination of the figures presented by Rathbun $(1923,1926,1935)$ and according to Förster (1966: 125), we consider that the American species (largely based on fragmentary specimens) are not representatives of Erymidae. As for the Lebanese species, we follow Charbonnier et al. (in press) with the placement in Pustulina. In conclusion, Eryma vocontii n. sp. is the hitherto youngest occurrence of the genus Eryma.

Eryma glaessneri (Van Straelen, 1936)

(Fig. 4G-H)

Enoploclytia glaessneri Van Straelen, 1936: 10-11, pl. 3, fig. 1.

Enoploclytia glaessneri - Secrétan 1964: 35, 94. — Schweitzer et al. 2010: 22.

Eryma glaessneri - Förster 1966: 123, fig. 22 (non pl. 17, fig. 3). — Feldmann \& Titus 2006: 63. Karasawa et al. 2008: 104.

TYPE MATERIAL. - Holotype MNHG GEPI 28369 housed in MHNG (Van Straelen coll.) (cast MNHN.F.R10204).

TYPE LOCALITY. - Escragnolles, Alpes-Maritimes department, Provence-Alpes-Côte d'Azur region, southeastern France.

TYPE AGE. - Hauterivian, Early Cretaceous.

DESCRIPTION. - Subcylindrical carapace (holotype: $\mathrm{CL}=55 \mathrm{~mm}, \mathrm{CH}=36 \mathrm{~mm}$ ); rostrum not preserved; intercalated plate present but poorly preserved; wide cardiac region and inflated branchial region; deep cervical groove, joined to dorsal margin and to antennal groove, straight and strongly inclined above gastro-orbital groove, straight and subvertical under gastro-orbital groove; cephalic region with oblique orbital row of tubercles (antennal not preserved); deep antennal groove, as wide as cervical groove, strongly curved and delimiting raised antennal lobe, shallowest in its anterior end; long, wide gastro-orbital groove originating as deep and large inflexion of cervical groove; wide postcervical groove, dorsally deep, curved forward, strongly inclined, joined to 
dorsal margin and joined medially to branchiocardiac groove, extended with a long, shallow ventral extension; shallow branchiocardiac groove, shallowest at carapace midheight, subparallel to postcervical groove, strongly inclined, joined to dorsal margin in posterior-most part of branchial region; narrow, deep hepatic groove, posteriorly concave, anteriorly slightly convex, joined to cervical groove; slightly inflated $\omega$ bulge, delimited ventrally by a narrow and shallow depression extending between antennal and hepatic grooves; flat attachment site of adductor testis muscle ( $\chi$ bulge); deep inferior groove; carapace covered with shallow depressions between small tubercles; cardiac region with an oblique row of coarse tubercles; gastric region with two rows of coarse tubercles parallel to intercalated plate.

Discussion. - This species was originally assigned to Enoploclytia M'Coy, 1849 by Van Straelen (1936). Later, Förster (1966) placed it in Eryma; this act was followed by all successive authors until the work by Schweitzer et al. (2010) who re-established Van Straelen's opinion. The re-examination of the holotype leads us to concur with Förster's proposition. Indeed, the carapace groove pattern (postcervical and branchiocardiac grooves joined medially) is diagnostic of Eryma.

We note that Förster (1966: pl. 17, fig. 3) figured a specimen which is clearly not Eryma glaessneri, because it exhibits carapace groove pattern (branchiocardiac groove interrupted in carapace mid-height; sinuous postcervical groove) typical of Enoploclytia.

\section{Eryma sulcatum Harbort, 1905}

(Fig. 4I-L)

Eryma sulcata Harbort, 1905: 15, pl. 1, fig. 11, pl. 11, fig. 4.

Astacodes falcifer (pars.) - Bell 1863: pl. 9, fig. 7-8.

Eryma sulcata - Glaessner 1929: 159. — Woods 1930: 80, pl. 22, fig. 5-7. — Van Straelen 1936: 9. — Förster 1966: 124, fig. 23, pl. 17, fig. 2 and 4. — Taylor 1979: 34. — Feldmann \& Titus 2006: 64.

Eryma cf. sulcata - Aguirre-Urreta \& Ramos 1981: 610, pl. 1, fig. a.

Eryma sulcatum - Schweitzer et al. 2010: 25. — Karasawa et al. 2013: 102.

TYPE MATERIAL. - Neotype herein designated SM B11437, specimen figured by Woods (1930: pl. 22, fig. 5a, b). After Harbort (1905), the original type material was composed of at least 3 specimens from the Hauterivian of Stadthagen near Schaumburg (Lower Saxony, Germany). After Förster (1966: 124) and Morris (1980: 7), these specimens were destroyed during World War II and only poorly preserved casts are housed at the NHM, London (see Woods 1930: 80 and Förster 1966: 124). Förster (1966) designated a lectotype based on a cast corresponding to the carapace figured by Harbort (1905: pl. 1, fig. 11a, b). After examination, the quality of this cast is not good enough to be used and we consider important to select a neotype for Eryma sulcatum. 
We select the historical specimen SM B11437, which is three-dimensionally preserved and fits the original diagnosis according to Woods (1930), Förster (1966) and to our own observations (Fig. 4I, K). The new type locality is Speeton in northern England. After Woods (1930), the specimen was collected in the C4 bed of the Speeton Clay, which corresponds to the Hauterivian after Fletcher (1969).

TYPE LOCALITY. - Speeton, Yorkshire, United Kingdom.

TYPE AGE. - Hauterivian, Early Cretaceous (Speeton Clay C Beds).

DESCRIPTION. - Subcylindrical carapace (neotype: $\mathrm{CL}=$ ca $32 \mathrm{~mm}$, visible $\mathrm{CH}=$ ca 12 $\mathrm{mm}$ ); short rostrum; fusiform, tuberculate intercalated plate limited by a row of coarse tubercles; almost smooth post-orbital area; cephalic region with oblique orbital row of tubercles ending by strong orbital spine (antennal row absent); deep cervical groove, intercepting dorsal margin at $c a 66^{\circ}$ angle, joined to antennal groove; short gastroorbital groove originating as a slight median inflexion of cervical groove; postcervical groove slightly convex forward, interrupted before joining dorsal margin, joined medially to branchiocardiac groove; deep branchiocardiac groove, strongly inclined, interrupted before joining dorsal margin, joined to hepatic groove; concavo-convex hepatic groove; slightly inflated $\omega$ bulge, delimited ventrally by a narrow and shallow depression extending between antennal and hepatic grooves; slightly inflated $\chi$ bulge; inferior groove curved forward; carapace showing dense ornamentation of small tubercles and pits; branchial region with finer tubercles; pleon densely covered with small numerous tubercles and pits; s1-s3 pleura with pointed ventral margin; pleonal somites with terga densely covered by small pits; longitudinal bulge above pleura basis; subtriangular pleura with pointed ventral margin, wide and short in s2, narrower and longer in s3 and s4, densely covered with small pits; chelate P1; massive P1 propodus, longer than wide, relatively thick with rounded inner and outer margins; P1 palm densely covered with small tubercles and deep pits; fingers not preserved; short P1 carpus, showing coarser ornamentation than propodus, distal extremity of external margin bearing a strong spine; P1 merus with the same ornamentation than P1 carpus, with spines on the dorsal margin and a spine on the distal extremity of external margin; slender, P2-P5 with a small punctation.

DISCUSSION. - Eryma sulcatum shows a heterogeneous ornamentation (branchial region with fine tubercles, cardiac and cephalic regions with coarser tubercles). This observation is not common among most of the representatives of Eryma, which exhibits more homogeneous and fine ornamentation on the whole carapace. It is worth mentioning that several Early Cretaceous species of Eryma exhibit the same heterogeneous and/or coarse ornamentation such as E. glaessneri (cephalic and cardiac regions with dorsal rows of strong tubercles; branchial region with fine tubercles) or E. nippon (coarse ornamentation). 
Genus Stenodactylina Beurlen, 1928

(Fig. 1D-F)

Stenodactylina Beurlen, 1928: 175.

Erymastacus Beurlen, 1928: 171.

Erymastacus — Secrétan 1964: 71. — Glaessner 1969: 456. — Hyžný et al. 2015: 375.

Stenodactylina - Glaessner 1969: 456. — Schweigert 2013: 411.

TYPE SPECIES. — Stenodactylina liasina Beurlen, 1928, by monotypy.

DisCUSSION. - Beurlen (1928) defined two genera based on of chelipeds, namely Erymastacus and Stenodactylina. Later, Erymastacus, with Glyphea ornati Quenstedt, 1857 as type species (subsequent designation by Glaessner 1929) was regarded by many authors as a junior synonym of Eryma (Förster 1966, Glaessner 1969, Schweitzer et al. 2010) while other authors considered it as a distinct genus (Secrétan 1964, Schweigert et al. 2000, Schweigert \& Garassino 2003, Hyžný et al. 2015). Hyžný et al. (2015) provided arguments in favor of the resurrection of Erymastacus, once considered as junior subjective synonym of Eryma, and the synonymisation of Stenodactylina with Erymastacus. Their study was based on new material of Erymastacus lagardettei Hyžný et al. 2015 (Middle Jurassic of Belmont, France), which was considered to be the only record in which Stenodactylina-type chelipeds are associated with their carapaces.

Careful examination of the lectotype of Glyphea ornati Quenstedt, 1857, leads us to a different conclusion. Indeed, this species clearly exhibits Eryma-like chelae (near-isochelous) instead of Stenodactylina-like chelae (distinctly heterochelous). In conclusion, we agree with Förster (1966), Glaessner (1969), and Schweitzer et al. (2010), we maintained the synonymy between Erymastacus and Eryma, and the combination Eryma ornatum (Quenstedt, 1857) is reinstalled. Finally, the concept of "Erymastacus" based on carapace and chelipeds proposed by Hyžný et al. (2015) is correct and should be renamed as "Stenodactylina".

SystematiC IMPLiCATIONS. - According to Hyžný et al. (2015), we consider that several species fit the concept of Stenodactylina (ex Erymastacus) such as:

(1) Eryma insignis Oppel, 1862; this species shows P1 chela with length and shape close to that of Eryma anisodactyla Krause, 1891. We consider that E. anisodactyla is a junior synonymous of E. insignis and we propose the new combination Stenodactylina insignis (Oppel, 1862).

(2) Erymastacus australis Secrétan, 1964; this species shows P1 chela exhibiting a rectangular propodus, a wide inflated dactylar bulge and slender fingers. These features support the placement in Stenodactylina. We propose the new combination Stenodactylina australis (Secrétan, 1964).

(3) Eryma falsani Dumortier, 1867; this species is known by a P1 chela showing a rectangular propodus, long and slender fingers and a row of coarse tubercles on dorsal 
surface of propodus. These characters support the assignment to Stenodactylina. Hence, we propose the new combination Stenodactylina falsani (Dumortier, 1867).

(4) Stenodactylina lagardettei (Hyžný et al., 2015) n. comb. exhibits P1 chelae typical of Stenodactylina.

Contrary to Hyžný et al. (2015), we consider that several species do not fit the concept of Stenodactylina (ex Erymastacus) such as:

(1) Eryma babeaui Étallon, 1861; this species possesses P1 chela typical of Eryma with trapezoidal propodus showing two longitudinal depressions and fingers curved inward and gradually narrowing distally.

(2) Eryma major Oppel, 1861; this species was synonymized with Eryma modestiforme (Schlotheim, 1822) by Garassino \& Schweigert (2006). However, the holotype exhibits a dentition of the fingers different from that in E. modestiforme. Eryma punctatum Oppel, 1861 has the same dentition, so E. major is probably a large specimen of E. punctatum.

(3) Erymastacus quenstedti Beurlen, 1928; this species exhibits P1 chela typical of Eryma with trapezoidal propodus and fingers curved inward and gradually narrowing distally. According to Schweitzer et al. (2010), we maintain the placement in Eryma.

(4) Eryma aalensis (Quenstedt, 1857); this species exhibits P1 chela typical of Eryma with trapezoidal propodus showing two longitudinal depressions and fingers curved inward and gradually narrowing to distal extremity.

Hyžný et al. (2015) did not list several species, which we consider here to be representatives of Stenodactylina such as:

(1) Enoploclytia armata Secrétan, 1964; this species shows P1 chela exhibiting a strong rectangular propodus, with inner margin more compressed than outer margin, rows of coarse tubercles in dorsal and ventral surfaces and on inner margin, and a wide inflated dactylar bulge. These features support the placement in Stenodactylina. We propose the new combination Stenodactylina armata (Secrétan, 1964).

(2) Enoploclytia triglypta Stenzel, 1945; this species exhibits a carapace groove pattern with postcervical groove not joined to branchiocardiac groove and interrupted in hepatic region. These features support the placement in Stenodactylina. We propose the new combination Stenodactylina triglypta (Stenzel, 1945).

(3) Eryma burgundiacum Crônier \& Courville, 2004; this species exhibits a carapace groove pattern with postcervical groove not joined to branchiocardiac groove and interrupted in hepatic region. These features support the placement in Stenodactylina. We propose the new combination Stenodactylina burgundiaca (Crônier \& Courville, 2004).

(4) Eryma granuliferum Secrétan, 1964; this species exhibits a carapace groove pattern with postcervical groove not joined to branchiocardiac groove and interrupted in hepatic region (see Charbonnier et al. 2012a: fig. 10). These features support the placement in Stenodactylina. We propose the new combination Stenodactylina granulifera (Secrétan, 1964).

(5) Eryma villersi Morière, 1883; the carapace groove pattern (postcervical groove not joined to branchiocardiac groove, interrupted in hepatic region) and the P1 chelae (elongate propodus, elongated, slender fingers) support the assignment to 
Stenodactylina. Hence, we proposed the new combination Stenodactylina villersi (Morière, 1883).

(6) Erymastacus strambergensis Bachmayer, 1959; this species shows P1 chela exhibiting a propodus with inner margin more compressed than outer margin, a row of coarse tubercles on inner margin, an inflated dactylar bulge, and a slender index basis. These features support the placement in Stenodactylina. We proposed the new combination Stenodactylina strambergensis (Bachmayer, 1959).

(7) Eryma walkerae Feldmann \& Haggart, 2007; this species exhibits a carapace groove pattern with postcervical groove not joined to branchiocardiac groove and interrupted in hepatic region. These features support the placement in Stenodactylina. We propose the new combination Stenodactylina walkerae (Feldmann \& Haggart, 2007).

(8) Eryma deslongchampsi Van Straelen, 1925; this species exhibits a carapace groove pattern with postcervical groove not joined to branchiocardiac groove and interrupted in hepatic region associated with a P1 chela with an elongate propodus and elongated, slender fingers. These features support the placement in Stenodactylina. We propose the new combination Stenodactylina deslonchampsi (Van Straelen, 1924).

EMENDED DIAGNOSIS. - Fusiform intercalated plate; very wide, deep cervical groove, joined to dorsal margin and to antennal groove; short gastro-orbital groove originating as a slight median inflexion of cervical groove; postcervical and branchiocardiac grooves nearly parallel; narrow postcervical groove, not joined to branchiocardiac groove and interrupted in hepatic region; branchiocardiac groove strongly inclined, joined to hepatic groove; concavo-convex hepatic groove, joined to cervical groove; inferior groove convex posteriorly, joined to hepatic groove; chelate P1; P1 propodus rectangular or trapezoidal, adorned with rows of spines and tubercles; P1 propodus with inner margin more compressed than outer margin; wide P1 dactylar bulge; P1 with extremely long and slender fingers, equal in length; P1 chela (form I; Fig. 1E) with strong, rectangular or trapezoidal propodus, with straight or sinuous fingers, strongly narrowing immediately after their basis; outer margin convex at the base of fixed finger; P1 chela (form II; Fig. 1F) with trapezoidal propodus, outer margin straight or convex, straight fingers, narrowing gradually to their distal extremity.

Stenodactylina delphinensis (Moret, 1946) n. comb.

(Fig. 5A-B)

Eryma delphinensis Moret, 1946: 49-51, fig. 3.

Eryma delphinensis — Förster 1966: 122-123. — Schweitzer et al. 2010: 23.

TYPE MATERIAL. - Holotype (OSUG.UJF-ID 11152, Touchon coll.).

TYPE LOCALITY. - Noyarey, Isère department, Rhône-Alpes region, southeastern France. 
TYPE AGE. - Berriasian, Early Cretaceous.

DESCRIPTION. - Subcylindrical carapace (holotype: $\mathrm{CL}=36 \mathrm{~mm}$; $\mathrm{CH}=17 \mathrm{~mm}$ ); short toothless rostrum; fusiform intercalated plate; slightly curved ocular incision; narrow tuberculate post-orbital area; wide cephalic region, extending at almost half of carapace length; wide, deep cervical groove, strongly inclined, joined to dorsal margin and to antennal groove; narrow antennal groove; short gastro-orbital groove originating as a slight median inflexion of cervical groove; postcervical and branchiocardiac grooves subparallel; deep and narrow postcervical groove, strongly inclined and curved forward, intercepting dorsal margin, interrupted in hepatic region; shallow branchiocardiac groove, as wide as postcervical groove, deeper towards its junction to hepatic groove, not joined to dorsal margin, joined to hepatic groove; narrow, hepatic groove, shallow, concave posteriorly, slightly convex anteriorly, joined to cervical groove; flat attachment site of adductor testis muscle ( $\chi$ bulge); wide and deep inferior groove, convex posteriorly, joined to hepatic groove; carapace ornamentation made of small tubercles delimited anteriorly by shallow depressions; ornamentation growing more dense towards branchial region.

DisCUSSION. - The examination of the holotype reveals the absence of a junction between postcervical and branchiocardiac grooves which remain subparallel until postcervical groove interrupts in hepatic region. This carapace groove pattern is typical of Stenodactylina. Stenodactylina delphinensis (Moret, 1946) n. comb. is the only representative of the genus for the Early Cretaceous.

In addition, the holotype presents a carapace in butterfly-like position with a strong dorsoventral flattening along the dorsal midline (Fig. 5A). This layout is characteristic of a lobster molt (Glaessner 1969; Charbonnier et al. 2012b). A rupture of the dorsal midline is observed with a slight rotation of the two halves of carapace. This suggest a probable hinge-type opening during ecdysis (Charbonnier et al. 2012b).

Genus Palaeastacus Bell, 1850

(Fig. 1G-H)

Palaeastacus Bell, 1850: 344.

Palaeastacus — Zittel 1885: 695. — Beurlen 1928: 180. — Förster 1966: 126. — Taylor 1979: 26. — Aguirre-Urreta \& Ramos 1981: 606. — Aguirre-Urreta 1989: 509. — Schweitzer \& Feldmann 2001: 174. — Hyžný et al. 2015: 375. — Feldmann et al. 2015: 3.

Enoploclytia (Palaeastacus) — Mertin 1941: 161. — Glaessner 1969: 455.

TYPE SPECIES. - Astacus sussexiensis Mantell, 1824, by subsequent designation of Glaessner (1929). 
EMENDED DIAGNOSIS. - Fusiform intercalated plate with tubercles; deep cervical groove, joined to dorsal margin and to antennal groove; short gastro-orbital groove originating as a slight median inflexion of cervical groove; postcervical and branchiocardiac grooves nearly parallel, both joined to hepatic groove; concavo-convex hepatic groove, joined to cervical groove; inferior groove convex posteriorly, joined to hepatic groove; longitudinal rows of sub-spiny tubercles in gastric region, diagonal rows of tubercles on cardiac region; massive chelate P1; P1 propodus short, thick, slightly globose, inner margin more compressed than outer margin, longitudinal rows of spiny tubercles on dorsal and ventral surfaces, inner margin bearing strong spines; P1 palm with narrow dactylar bulge; wide fingers, slightly longer than propodus, gradually narrowing to distal extremity; index with basally curved occlusal margin.

\section{Palaeastacus sussexiensis (Mantell, 1824)}

(Fig. 6, 7A-E)

Astacus sussexiensis Mantell, 1824: 11, pl. 29, fig. 15.

Enoploclytia imagei M'Coy, 1849: 331.

Enoploclytia brevimana M'Coy, 1849: 332.

Palaeastacus dixoni Bell, 1850: 344, 345, pl. 38, fig. 1-5.

Hoploparia scabra Bell, 1863: 28, pl. 7, fig. 3-7.

Phlyctisoma granulatum Bell, 1863: 36, pl. 11, fig. 9-10.

Palaeastacus plauensis Geinitz, 1875: 291, pl. 64, fig. 9.

Astacus leachii (pars) — Mantell 1822: 223, pl. 30, fig. 3.

Astacus sussexiensis — Mantell 1833: 124, 373, 379, fig. 2. — Mantell 1844: 238, fig.4. — Quenstedt 1852: 269. — Quenstedt 1885: 411, fig. 129.

Glyphea sussexiensis — Roemer 1841: 105.

Enoploclytia imagei - M'Coy 1854: 136. — Reuss 1854: 3. — Woodward 1877: 9. — Glaessner 1929: 146. - Schweitzer et al. 2010: 22.

Enoploclytia brevimana - M'Coy 1854: 137. - Reuss 1854: 3. - Bronn 1851-1852: 352 . Woodward 1877: 9. - Schweitzer et al. 2010: 22.

Enoploclytia sussexiensis - Morris 1854: 108. - Willet 1871: 42-43. — Woodward 1877: 10. Woodward 1878: 377, pl. 38, fig. 1-4. — Schlüter 1879: 602. — Van Straelen 1936: 12.

Palaeastacus dixoni — Geinitz 1875: 292. — Schlüter 1879: 602.

Palaeastacus sussexiensis — Glaessner 1929: 200. — Rathbun 1935: 23. — Förster 1966: 133, fig. 24, pl. 17, fig. 6. - Aguirre Urreta 1981: 609, fig. 4c. — Morris 1987: 196, pl. 42, fig. 4-5. — Aguirre Uretta 
1989: 510, fig. 8-10. — Wittler 1998: 18, fig. 5. — Garassino \& Schweigert 2006: 11. — Schweitzer et al. 2010: 26. - Karasawa et al. 2013: 79, 102.

Hoploparia scabra - Glaessner 1929: 221.

Palaeastacus ? plauensis — Glaessner 1929: 290.

Phlyctisoma granulatum — Glaessner 1929: 314. — Monaco \& Garassino 2000: 297.

Enoploclytia dixoni - Woods 1930: 83, pl. 23, fig. 9-12, pl. 24, fig. 1-3. — Van Straelen 1936: 11.

Enoploclytia (Palaeastacus) sussexiensis - Mertin 1941: 161, fig. 4a.

Enoploclytia (Palaeastacus) imagei - Roberts 1962: 164.

Palaeastacus scaber — Förster 1966: 132, fig. 26, pl. 17, fig. 7-9. — Schweitzer \& Feldmann 2001: 174.

— Garassino \& Schweigert 2006: 11. - Schweitzer et al. 2010: 25. — Karasawa et al. 2013: 102.

Palaeastacus cf. sussexiensis - Taylor 1979: 30, fig. 10e, pl. 4 fig. d-f.

Palaeastacus dixoni - Schweitzer et al. 2010: 25.

Palaeastacus ? plavensis - Schweitzer et al. 2010: 25.

Pustulina granulata - Schweitzer et al. 2010: 26.

Pustulina scabra - Schweitzer et al. 2010: 26.

TYPE MATERIAL. - According to Morris (1980), Förster (1966: 134) selected as a lectotype of Palaeastacus sussexiensis one of the syntypes of Palaeastacus dixoni Bell, 1850; obviously the selection should have been made on the original type material of Mantell (1824). So the specimen NHMUK 5601, from the original type material of Mantell, is herein designated as lectotype. 13 paralectotypes are also considered: NHMUK 5024, 5584, 5586, 5589, 5600, 5602, 5608, 5613, 5618, 5624, 5626, 5629, 10760 .

TYPE LOCALITY. - Sussex, United Kingdom (precise type locality not indicated on the original labels).

TYPE AGE. - Cenomanian, Late Cretaceous.

DESCRIPTION. - Carapace sub-cylindrical (lectotype: $\mathrm{CL}=82 \mathrm{~mm}, \mathrm{CH}=41 \mathrm{~mm}$ ); long spiny rostrum; fusiform and tuberculate intercalated plate; ridge on dorsal margin of branchial region; deep cervical groove, joined to dorsal margin and to antennal groove; deep antennal groove; short gastro-orbital groove originating as a slight median inflexion of cervical groove; postcervical and branchiocardiac grooves subparallel; dorsally deep, sinuous postcervical groove, shallowing ventrally, not joined to dorsal margin, joined to hepatic groove; narrow branchiocardiac groove, strongly inclined, 
shallower than postcervical groove, not joined to dorsal margin, joined to hepatic groove; concavo-convex, narrow hepatic groove, joined to cervical groove; inflated $\omega$ bulge; flat attachment site of adductor testis muscle ( $\chi$ bulge); deep inferior groove, joined to hepatic groove; carapace densely covered with rounded tubercles in branchial region and widely spaced coarse tubercles in gastric, hepatic and cephalic regions; row of coarse tubercles parallel to dorsal margin in cardiac and branchial regions; two oblique rows of coarse tubercles in cardiac region; two rows of tubercles parallel to the intercalated plate in gastric region; pleonal somites with terga ornamented by three pairs of strong dorsal spines and by rounded, coarse tubercles on the remaining surface; subtriangular pleura, with pointed ventral margin, ornamented with strong spines; telson with rounded extremity; telson with longitudinal median ridge flanked by two wide lateral ridges interrupted at telson mid-length; telson covered with coarse rounded tubercles; uropods as long as telson, covered by tubercles; uropodal endopod with longitudinal carina; uropodal exopod with diaeresis; chelate P1; short, trapezoidal, slightly globose P1 propodus, with two divergent rows of spines on ventral and dorsal surfaces; inner margin with strong spines; wide fingers, slightly longer than propodus; occlusal margins with short, spaced teeth; index wider than dactylus; dactylus adorned with spines; spiny P1 carpus and merus.

Discussion. - The original type material of Astacus leachii Mantell, 1822 was heterogeneous and composed of a set of P1 chelae and fragments of carapaces. Among these chelae, Mantell (1824) distinguished Astacus sussexiensis (short, spiny chelae with short fingers) from A. leachii (chelae with long fingers). Later, numerous authors regarded A. sussexiensis as a representative of Enoploclytia (Morris 1854; Willet 1871; Woodward 1877, 1878; Van Straelen 1936; Mertin 1941). Bell (1850) described Palaeastacus dixoni which type material is composed of an isolated pair of P1 chelae, some P1 chelae connected with carapaces and a complete carapace preserved in connection with a complete pleon (Fig. 6F, Bell 1850: pl. 38, fig. 1). The latter specimen was designated by Woods (1930) as the lectotype of Enoploclytia dixoni (Bell, 1850). Woods (1930) also considered A. sussexiensis, Enoploclytia brevimana M'Coy, 1849, Hoploparia scabra Bell, 1863 (Fig. 7B-C), and Phlyctisoma granulatum Bell, 1863 (Fig. 7D-E) as junior synonyms of E. dixoni. Förster (1966), recently followed by Karasawa et al. (2013), distinguished Palaeastacus sussexiensis (Mantell, 1824) (including as synonyms: A. sussexiensis, Enoploclytia imagei M'Coy, 1849, E. brevimana, P. dixoni and Palaeastacus plauensis Geinitz, 1875) and Palaeastacus scaber (Bell, 1863) (including as synonyms: H. scabra and P. granulatum). Lastly Schweitzer et al. (2010) re-established the distinction between E. brevimana, E. imagei, $P$. granulatum, $P$. plauensis, $P$. dixoni, $P$. scaber and $P$. sussexiensis.

Our re-examination of the type specimens reveals that the P1 chelae of $P$. sussexiensis and $P$. dixoni are similar (short, spiny P1 propodus with narrow dactylar bulge and bearing wide fingers). Moreover, the carapaces of $P$. dixoni, P. granulatum and H. scabra show the same groove pattern (nearly parallel postcervical and branchiocardiac grooves joined to hepatic groove and not joined to dorsal margin) and the same ornamentation (branchial region densely covered with tubercles; widely 
spaced tubercles in gastric, hepatic and cephalic regions; row of coarse tubercles parallel to dorsal margin in cardiac and branchial regions; oblique rows of coarse tubercles in cardiac region). Thus, we follow Woods (1930) and consider $A$. sussexiensis, $P$. dixoni, $H$. scabra and $P$. granulatum as a unique species: Palaeastacus sussexiensis (Mantell, 1824). E. brevimana (Fig. 6E) and E. imagei (Fig. 7A) have not been figured until now. Both have spiny P1 chelipeds; short P1 propodus with short and wide fingers as $P$. sussexiensis. Moreover, a syntype of E. imagei includes a carapace (Fig.7A) with a long rostrum, a groove pattern and an ornamentation close to $P$. sussexiensis. The type material of P.plauensis is an incomplete P1 propodus and fragments of wide fingers coarsely ornamented close to those of $P$. sussexiensis. Finally our review leads us to recognise $P$. dixoni, E. imagei, E. brevimana, H. scabra, $P$. granulatum and $P$. plauensis as junior synonyms of $P$. sussexiensis.

In addition, Palaeastacus sussexiensis (Mantell, 1824) had a wide geographic distribution and a stratigraphic range from the Aptian to the Turonian. Indeed, this species has been reported (1) from the Aptian of Alexander Island (Antarctic; Taylor 1979) and Patagonia (Argentina; Aguirre-Urreta 1989), (2) the Albian of England (Bell, 1863; Woods, 1930; Förster 1966), (3) the Cenomanian of England (Bell 1850; Förster 1966; Morris 1987), Germany (Mertin 1941) and France (Van Straelen 1936; Förster 1966), and (4) the Turonian of England (Mantell 1822, 1833, 1844; Morris 1987) and Germany (Wittler 1998).

Palaeastacus loryi (Van Straelen, 1923) n. comb.

(Fig. 7F, G)

Eryma loryi Van Straelen, 1923: 93.

Eryma loryi - Glaessner 1929: 155. — Van Straelen 1936: 7-8, pl. 1, fig. 6. - Moret 1946: 50, fig. 1. — Roger 1946: 42. — Secrétan 1964: 69. — Förster 1966: 123. — Feldmann \& Titus 2006: 64. — Schweitzer et al. 2010: 24.

TYPE MATERIAL. - Holotype (OSUG, probably lost).

TYPE LOCALITY. - Malleval, Isère department, Rhône-Alpes region, southeastern France.

TYPE AGE. — Valanginian, Early Cretaceous.

DESCRIPTION. - Subcylindrical carapace (holotype: $\mathrm{CL}=60 \mathrm{~mm}, \mathrm{CH}=30 \mathrm{~mm}$ ); deep cervical, postcervical and branchiocardiac grooves; short gastro-orbital groove originating as a slight median inflexion of cervical groove; short antennal groove; postcervical groove parallel to branchiocardiac groove, not joined to dorsal margin, joined to hepatic groove; branchiocardiac groove, joined to dorsal margin, slightly sinuous dorsally, joined to hepatic groove; concavo-convex hepatic groove, poorly 
preserved; carapace homogeneously and densely covered with small tubercles following crescent-shaped pits.

DisCUSSION. - The holotype was not found in the palaeontological collections of OSUG at Grenoble, France. Our review of the species is based on the line drawing and the figure presented by Van Straelen (1923: fig. 93) and Van Straelen (1936: pl.1, fig. 6) respectively. Firstly, the line drawing is misleading by exhibiting intercalated plate not visible on the figure. Indeed, the cephalic part clearly appears to be crushed. Moreover, the carapace grooves seem to be incompletely reported. The examination of the figures leads us to identify the postcervical groove parallel to the branchiocardiac groove and joined to the hepatic groove. This pattern is typical of Palaeastacus. Hence, the new combination Palaeastacus loryi (Van Straelen, 1923) is proposed herein.

Other species of Palaeastacus are known from the Early Cretacous such as Palaeastacus foersteri Taylor, 1979 (Barremian of Alexander Island, Antarctic; Fig. 3A-B), Palaeastacus tenuidigitatus (Woods, 1957) n. comb. (Aptian of Queensland, Australia; see comments about Enoploclytia), and Palaeastacus terraereginae (Etheridge Jr., 1914) (Barremian of Patagonia, Argentina; Aptian of Alexander Island, Antarctic; Aptian of Queensland, Australia).

A short, spiny P1 chela from the Albian of Texas was assigned tentatively to a new species Paramithrax H. Milne Edwards, 1834 by Whitfield (1883): ?Paramithrax walkeri. Merril (1905) and Adkins (1928) followed Whitfield, but Rathbun (1935) emended his description and assigned this species to Palaeastacus. Rathbun (1935: pl. 3, figs 7-9) figured the holotype of P. walkeri (Whitfield, 1883) and included new material in this species (carapace, P1 chela, left P1 cheliped). Stenzel (1945) assigned P. walkeri to Enoploclytia and refigured the carapace added by Rathbun (1935). He also figured new material (complete right P1 cheliped, left P1 dactylus, two pleons). Following Stenzel (1945), Richardson Jr. (1955) figured a right P1 cheliped under the name Enoploclytia walkeri (Whitfield, 1883) but in a new variety: E. walkeri, var. schmidti. In his review, Förster (1966), later followed by Schweitzer et al. (2010), re-assigned the species to Palaeastacus.

Our review of the all the figured specimens reveals that the holotype of $P$. walkeri fits the concept of Palaeastacus (short, rectangular propodus, strong spines on dorsal and ventral surfaces and on dactylus, narrow dactylar bulge). Furthermore, the P1 chelae figured by Rathbun (1935: pl. 5, figs 1-3) and by Stenzel (1945: pl. 38, fig.1), the P1 dactylus figured by Stenzel (1945: fig. 8), and the P1 chelipeds figured by Rathbun (1935: pl. 5, fig. 4) and Richardson Jr. (1955: fig. 108) are similar to the holotype of P. walkeri. The two pleons figured by Stenzel (1945: fig. 9, pl. 38, fig. 2) probably also belong to P. walkeri. However, the carapace figured by Rathbun (1935: pl. 4, figs 1-2) and by Stenzel (1945: pl. 39, fig. 1) exhibits a long gastro-orbital groove, a sinuous postcervical groove joined to hepatic groove and a short branchiocardiac groove. This groove pattern is typical of Enoploclytia so this carapace cannot be regarded as P. walkeri but as a new species of Enoploclytia (see section Enoploclytia). 
In conclusion, with six species, Palaeastacus is the erymid genus including the most species for the Early Cretaceous.

Genus Enoploclytia M'Coy, 1849

(Fig. 1I-J)

Enoploclytia M'Coy, 1849: 330.

Enoploclytia - M'Coy 1854: 137. — Zittel 1885: 694. — Fritsch \& Kafka 1887: 27. — Van Straelen 1925: 278. — Beurlen 1928: 164. — Rathbun 1926: 128. — Secrétan 1964: 81. — Förster 1966: 146. — Taylor 1979: 25. — Aguirre Urreta 1989: 514. — Feldmann et al. 2015: 3.

Enoploclytia (Enoploclytia) - Mertin 1941: 160. — Glaessner 1969: 455.

TYPE SPECIES. - Astacus leachii Mantell, 1822, by original designation.

EMENDED DIAGNOSIS. - Fusiform intercalated plate; wide, deep cervical groove, joined to dorsal margin and to antennal groove; long, wide gastro-orbital groove originating as median inflexion of cervical groove, delimiting two gastro-orbital lobes; sinuous postcervical groove, joined to dorsal margin and to hepatic groove, with ventral extension at carapace mid-height; short branchiocardiac groove, interrupted in upper part of carapace, joined to dorsal margin, not joined to postcervical groove; concavoconvex hepatic groove, joined to cervical groove; prominent $\omega$ and $\chi$ bulges; inferior groove convex posteriorly, joined to hepatic groove; carapace with heterogeneous coarse ornamentation; massive globose P1 propodus, rounded in transversal section; long and thin P1 fingers (straight in dorsal view); occlusal margins armed with sharp and slender tooth.

PRELIMINARY REMARKS. - Out of numerous species of Enoploclytia listed by Schweitzer et al. (2010), five are known from the Early Cretaceous. Among these species, two are from the Hauterivian of France: Enoploclytia glaessneri Van Straelen 1936, which belongs to Eryma (see comments about Eryma glaessneri), and Enoploclytia salviensis (Robineau-Desvoidy, 1849). The type material of E. salviensis is lost for a long time and the species is only known by the figures presented by Robineau-Desvoidy (1849): some fragments of P1 fingers and a carapace. The fragments of fingers are curved with numerous short and close teeth, while fingers of Enoploclytia are straight with long, slender and spaced teeth. Furthermore, the illustrations of the carapace is not clear enough to assign it to any genus of decapod crustaceans.

Two other species come from the Albian of Texas. Enoploclytia wintoni Stenzel, 1945 is known by a pair of chelae with globose and coarsely tuberculate propodus and slender denticulate fingers typical of Enoploclytia. Enoploclytia wenoensis Rathbun, 1935 , is known by a single pleon with terga without relief, densely covered with small pits and rounded pleura. Usually species of Enoploclytia have a pleon with more relief 
(longitudinal bulges on pleura basis; coarse, widely spaced ornamentation) and triangular, sharp pleura. Then, following Stenzel (1945) and Förster (1966), we conclude that E. wenoensis is probably not a representative of Enoploclytia but maybe a representative of Astacodes Bell, 1863, Hoploparia M'Coy, 1849, or Homarus Weber, 1795.

Enoploclytia tenuidigitata Woods, 1957 (Aptian of Queensland, Australia) is known by some fragments of carapace, P1 chelae and pleon. The carapace groove pattern with postcervical and branchiocardiac grooves joined to hepatic groove is typical of Palaeastacus. So E. tenuidigitata should be assigned to Palaeastacus; thus a new combination Palaeastacus tenuidigitatus (Woods, 1957) is proposed herein.

Taylor (1979), Aguirre Urreta (1982) and Garassino et al. (2009) reported fragments of chelae attributed to Enoploclytia sp. from the Aptian of Alexander Island (Antarctic), the Barremian of Patagonia (Argentina) and the Aptian of Catalonia (Spain), respectively. Finally, E. wintoni and the fragments of chelae discussed above have until now been the only reports of Enoploclytia from the Early Cretaceous.

\section{Enoploclytia augustobonae n. sp.}

(Fig. 8A-D)

ETYMOLOGY. - The specific epithet refers to Augustobona, the Latin name of Troyes, the regional capital near the type locality.

TYPE MATERIAL. - Holotype MNHN.F.B14557.

TYPe LOCALITY. - Amance, Aube department, Champagne-Ardennes region, East France.

TYPE AGE. - Barremian, Early Cretaceous.

DESCRIPTION. - Subcylindrical carapace (holotype: $\mathrm{CL}=63 \mathrm{~mm}, \mathrm{CH}=33 \mathrm{~mm}$ ); rostrum not preserved; intercalated plate not preserved but underlined by a slight deviation of dorsal margin in cephalic region; deep cervical groove, joined to dorsal margin and to antennal groove, strongly inclined above gastro-orbital groove, subvertical under gastro-orbital groove; deep, shallow antennal groove, strongly curved; wide, shallow gastro-orbital groove originating as large median inflexion of cervical groove, with two divergent branches, delimiting two gastro-orbital lobes (flat upper lobe, slightly prominent lower lobe); sinuous postcervical groove, dorsally deep and ventrally shallow, joined to dorsal margin and to hepatic groove, with ventral extension at carapace mid-height; short, shallow branchiocardiac groove, joined to dorsal margin and not to postcervical groove; concavo-convex hepatic groove, joined to cervical groove; inflated $\omega$ bulge; slightly inflated $\chi$ bulge; shallow inferior groove; cephalic region without antennal row of tubercles; carapace covered with small, widely spaced 
tubercles; cardiac region with a dorsal row of coarse tubercles; gastric region with a row of coarse tubercles parallel to intercalated plate and an oblique row of coarse tubercles.

Discussion. - The new species is assigned to Enoploclytia based on its typical carapace groove pattern: wide gastro-orbital groove, postcervical groove joined to hepatic groove, short branchiocardiac groove not joined to postcervical nor to hepatic grooves. It is also the oldest occurrence of Enoploclytia.

Enoploclytia augustobonae n. sp. cannot be compared to Enoploclytia wintoni, which is only known by its P1 chelae.

Enoploclytia augustobonae n. sp. differs from Enoploclytia gigantea n. sp. by its carapace groove pattern with (1) a non-sinuous cervical groove, (2) a less incurved antennal groove, (3) a shorter and shallower gastro-orbital groove and (4) a longer ventral extension of postcervical groove. Furthermore the ornamentation of these two species is different: Enoploclytia augustobonae n. sp. exhibits fine tubercles on all the carapace surface and coarse tubercles along dorsal margin and in gastric region, while E. gigantea n. sp. has coarse tubercles in the upper half of carapace, fine tubercles in the lower half of carapace, and a row of strong spines along dorsal margin.

Our review leads us to consider the Hauterivian species E. glaessneri as a representative of Eryma and to exclude E. salviensis from the Erymidae. In conclusion Enoploclytia augustobonae n. sp. is currently the oldest occurrence of the genus.

\section{Enoploclytia gigantea $\mathrm{n}$. sp.}

(Fig. 8E-H)

ETYMOLOGy. - The specific epithet refers to the Latin giganteus, - $a$, -um (= enormous) alluding to the exceptional size of the carapace.

TYPE MATERIAL. - Holotype $\mathrm{n}^{\circ} 201$ stored in the collections of the Bureau of Economic Geology, Texas (after Rathbun 1935).

TYPE LOCALITY. - Fort Worth, Texas (United States of America).

TYPE AGE. - Albian, Early Cretaceous.

DESCRIPTION. - Carapace subrectangular in lateral view (holotype: $\mathrm{CL}=175 \mathrm{~mm}, \mathrm{CH}=$ $110 \mathrm{~mm}$ ); rostrum not preserved; deep, sinuous cervical groove, joined to dorsal margin and to antennal groove; deep antennal groove, strongly curved and delimiting a slightly raised antennal lobe; long gastro-orbital groove, originating as a deep median inflexion of cervical groove, with two divergent branches delimiting two gastro-orbital lobes (flat upper lobe, slightly prominent lower lobe); deep, sinuous postcervical groove (strong sinuosity at carapace mid-height), joined to dorsal margin and to hepatic groove, with short ventral extension; short, shallow branchiocardiac groove, strongly inclined, joined to dorsal margin and not to postcervical groove; sinuous hepatic groove, joined to 
cervical groove; strongly inflated $\omega$ bulge; flat attachment site of adductor testis muscle ( $\chi$ bulge); deep inferior groove; carapace covered with widely spaced tubercles; coarse tubercles in upper half of carapace and small tubercles in lower half of carapace; gastric region with a row of coarse tubercles parallel to intercalated plate; row of spines directed forward along dorsal margin.

DisCUSSION. - The present carapace was initially identified as Palaeastacus walkeri by Rathbun (1935), who was followed by Stenzel (1945; see discussion about Palaeastacus). Our examination of the type material of $P$. walkeri leads us to a different conclusion. Indeed, this carapace shows groove pattern typical of Enoploclytia (long gastro-orbital groove, postcervical groove joined to hepatic groove, short branchiocardiac groove not joined to postcervical nor to hepatic grooves).

As for Enoploclytia augustobonae n. sp., Enoploclytia gigantea n. sp. (known by its carapace) cannot be compared to Enoploclytia wintoni (only known by P1 chelae). For a comparison, see discussion on E. augustobonae n. sp.

In conclusion, Enoploclytia gigantea n. sp. possesses the biggest carapace currently known among all erymid lobsters.

Genus Pustulina Quenstedt, 1857

(Fig. 1K-L)

Pustulina Quenstedt, 1857: 807.

Phlyctisoma Bell, 1863: 34 .

Phlyctisoma — Zittel 1885: 695. — Secrétan 1964: 74. — Förster 1966: 135.

Pustulina — Feldmann et al. 2015: 3.

TYPE SPECIES. — Pustulina suevica Quenstedt, 1857, by monotypy.

EMENDED DIAGNOSIS. - Fusiform intercalated plate; inflated hepatic, cardiac and branchial regions; deep cervical groove, joined to dorsal margin and to antennal groove; deep, long gastro-orbital groove, originating as a slight median inflexion of cervical groove, with two divergent incurved branches, delimiting two gastro-orbital lobes; strongly inclined postcervical groove, inflected before joining hepatic groove, not joined to dorsal margin; short and shallow branchiocardiac groove, joined to dorsal margin and not joined to postcervical groove; concave hepatic groove, joined to cervical groove; shallow cardiac groove, straight, inclined forward, rising from postcervical groove, joined to dorsal margin; cephalic region with strongly tuberculate antennal row and distal antennal spine; carapace with tuberculate ornamentation; chelate P1-P3; P1 with strongly tuberculate ornamentation; short $\mathrm{P} 1$ propodus with fingers barely longer; P1 dactylus longer than P1 index. 
COMMENTS. - Pustulina shares some features with Enoploclytia. Both have an inflated branchial region, a well-developed gastro-orbital groove, usually divided in two branches, a short branchiocardiac groove not joined to the postcervical groove, a tuberculate antennal row, and usually a heterogeneous coarse ornamentation.

\section{Pustulina occitana n. sp.}

(Fig. 9A-D)

ETYMOLOGY. - The specific epithet refers to Occitània, the historical region in southern Europe where Occitan was the main language spoken.

TYPE MATERIAL. - Holotype MNHN.F.A57460 (Leroy coll.).

TYPE LOCALITY. - Laciterne-Boisset near Moulès-et-Baucels, Hérault department, Languedoc-Roussillon region, South France.

TYPE AGE. - Berriasian, Early Cretaceous.

DESCRIPTION. - Subcylindrical carapace (holotype: $\mathrm{CL}=28 \mathrm{~mm}, \mathrm{CH}=15 \mathrm{~mm}$ ); dorsal line inclined downward in cephalic region; inflated cardiac, hepatic and branchial regions; deep cervical groove, joined to dorsal margin and to antennal groove; deep antennal groove, twice as narrow as cervical groove; long gastro-orbital groove, originating as a slight median inflexion of cervical groove, with two divergent branches, delimiting two tuberculate gastro-orbital lobes (flat upper lobe, prominent lower lobe); deep, straight postcervical groove, wider than cervical groove, strongly inclined, not joined to dorsal margin, forming a faint notch in upper hepatic region; shallow branchiocardiac groove, interrupted in upper third of carapace height, joined to dorsal margin and not joined to postcervical groove; concave hepatic groove, joined to cervical groove; deep inferior groove, joined to hepatic groove; short cardiac groove, inclined forward, rising from postcervical groove, joined to dorsal margin; cephalic region with convex antennal row of strong tubercles; carapace with scabrous surface, entirely covered with rounded tubercles, coarse and widely spaced in antennal and gastric regions, becoming gradually smaller and nearby towards posterior and ventral parts of branchial region.

DisCUSSION. - The new species is assigned to Pustulina based on its typical carapace groove pattern: long gastro-orbital groove with two divergent branches, strongly inclined postcervical groove joined to hepatic groove, short and shallow branchiocardiac groove not joined to postcervical or to hepatic grooves, concave hepatic groove, and cardiac groove.

Pustulina occitana n. sp. differs from the other four Early Cretaceous species, mainly by its ornamentation and its carapace groove pattern. Compared to Pustulina victori (Van Straelen, 1936) n. n., the cardiac groove of P. occitana n. sp. is narrower, 
shallower and less inclined forward, the gastro-orbital groove is longer and the ornamentation is denser. Pustulina tuberculata (Bell, 1863) possesses a cephalic region with straight dorsal margin in lateral view, whereas in P. occitana $\mathrm{n}$. sp., the dorsal margin is inclined downward. Moreover, the carapace ornamentation in P. tuberculata is composed of homogeneous evenly spaced tubercles, whereas it is heterogeneous in P. occitana $\mathrm{n}$. sp. (cephalic region with coarse and more widely spaced tubercles; branchial region with nearby and smaller tubercles). P. occitana $\mathrm{n}$. sp. shows some differences from Pustulina colossea n. sp. in its carapace groove pattern: its cervical groove is not as sinuous as in P. colossea n. sp., its gastro-orbital groove is narrower, with a shorter upper branch, its postcervical groove is not gradually curved and its inferior groove is more strongly curved forward. Moreover P. occitana $\mathrm{n}$. sp. is devoid of prominent upper gastro-orbital lobe and its ornamentation is denser than in P. colossea n. sp. Pustulina spinulata Secrétan, 1964 (Valanginian-Hauterivian, Madagascar) is the only extra-European Pustulina species for the Early Cretaceous. As $P$. tuberculata, also $P$. spinulata possesses a straight dorsal margin in cephalic region (inclined downward in Pustulina occitana n. sp.). In addition, P. spinulata differs from P. occitana $\mathrm{n}$. sp. by its more inflated and spiny hepatic region and its homogeneous ornamentation in branchial region.

Pustulina victori nomen novum

(Fig. 9E-F)

Eryma tuberculata Van Straelen, 1936: 9, pl. 2, fig. 3.

Eryma tuberculata - Roger 1946: 42. — Secrétan 1964: 69.

Phlyctisoma sp. - Förster 1966: 144.

Eryma tuberculatum - Schweitzer et al. 2010: 25.

ETYMology. - The specific epithet honors Victor Van Straelen, who identified the new species.

TYPE MATERIAL. - Holotype (MHNC collection, probably lost).

TyPe LOCALiTY. - Leysse, Savoie department, Rhône-Alpes region, southeastern France.

TYPE AGE. - Berriasian, Early Cretaceous.

DESCRIPTION. - Subcylindrical carapace $(\mathrm{CL}=c a 46 \mathrm{~mm}$ with incomplete cephalic region, $\mathrm{CH}=24 \mathrm{~mm}$ ); inflated cardiac, hepatic and branchial regions; wide, deep cervical groove, straight, narrowing ventrally, joined to dorsal margin and to antennal groove; wide gastro-orbital groove; very wide, deep postcervical groove, straight, 
dorsally strongly inclined, narrowing under its inflexion, not joined to dorsal margin, joined to hepatic groove; wide, concave hepatic groove, joined to cervical groove; deep inferior groove, joined to hepatic groove; wide, straight cardiac groove, strongly inclined forward, rising from postcervical groove, probably joined to dorsal margin; carapace ornamented with coarse, widely spaced, rounded tubercles.

DISCUSSION. - The holotype is probably lost and the present description is based on the figure proposed by Van Straelen (1936). Its low resolution does not allow to see the branchiocardiac groove. If this groove is present, it is too shallow and narrow to be distinguished.

Initially assigned to Eryma by Van Straelen (1936), the species was reassigned to Phlyctisoma sp. (now Pustulina sp.) by Förster (1966) based on its typical groove pattern (long gastro-orbital groove, strongly inflected postcervical groove joined to hepatic groove, concave hepatic groove, cardiac groove). Our examination of the original figure leads us to confirm Förster's placement. Moreover, the ornamentation and the well-developed cardiac groove are substantial enough to maintain the validity of the species described by Van Straelen (1936). Consequently, this situation leads to a case of secondary homonymy. To solve this problem and according to ICZN (1999: articles 53.3, 57.3), we propose herein the replacement name Pustulina victori pro P. tuberculata (Van Straelen, 1936) non P. tuberculata (Bell, 1863).

Pustulina colossea n. $\mathrm{sp}$.

(Fig. 9G-H)

ETYMOLOGY. - The specific epithet refers to the massive size and appearance of the carapace for a representative of Pustulina.

TYPE MATERIAL. - Holotype MNHN.F.A57459 (Leroy coll.).

TYPe LOCAliTy. - Castellane, Alpes-de-Haute-Provence department, Provence-AlpesCôte d'Azur region, southeastern France.

TYPE AGE. - Hauterivian, Early Cretaceous.

DESCRIPTION. - Subcylindrical carapace (holotype: $\mathrm{CL}=$ ca $50 \mathrm{~mm}$ with incomplete branchial region, $\mathrm{CH}=29 \mathrm{~mm}$ ); rostrum not preserved; cephalic region with dorsal line strongly inclined downward; strongly inflated cardiac, hepatic and branchial regions; wide, deep cervical groove, subvertical, slightly sinuous at level of gastro-orbital groove, narrowing above its junction to hepatic groove, joined to dorsal margin and to antennal groove; narrow, shallow antennal groove, strongly curved towards anterior margin; wide, deep gastro-orbital groove, originating as a median inflexion of cervical groove, with two divergent branches delimiting two inflated gastro-orbital lobes; wide postcervical groove, strongly inclined in dorsal branchial region and arcuate before 
joining hepatic groove, forming a notch in upper hepatic region; deep, concave hepatic groove, joined to cervical groove; inferior groove joined to hepatic groove; shallow, straight cardiac groove, rising from postcervical groove, slightly inclined forward, joined to dorsal margin; carapace entirely covered with rounded tubercles, coarser and more widely spaced forward postcervical groove, thinner and closer in branchial and pterygostomial regions; row of coarse tubercles parallel to intercalated plate; cephalic region with convex antennal row of tubercles and distal antennal spine.

Discussion. - Pustulina colossea $\mathrm{n}$. sp. is assigned to Pustulina based on its typical carapace groove pattern: long gastro-orbital groove with two branches, postcervical groove joined to hepatic groove, concave hepatic groove and cardiac groove.

Pustulina colossea n. sp. differs from Pustulina tuberculata and Pustulina spinulata by the cephalic region with dorsal margin strongly inclined downward (straight in the latter), its postcervical groove curved in dorsal branchial region (straight in the latter), its prominent upper gastro-orbital lobe (flat in the latter), and its heterogeneous ornamentation (homogeneous in in the latter). The differences between P. colossea n. sp. and Pustulina occitana n. sp. are described in the discussion about P. occitana n. sp.

Among Pustulina species, P. colossea n. sp. is the only one showing a curved postcervical groove and a raised upper gastro-orbital lobe. Furthermore, some morphological characters of $P$. colossea $\mathrm{n}$. sp., in particular the width of cervical and gastro-orbital grooves and the massive appearance of the carapace, are also encountered in Enoploclytia.

Pustulina tuberculata (Bell, 1863)

(Fig. 9I-L)

Phlyctisoma tuberculatum Bell, 1863: 35, pl. 11, fig. 1-8.

Phlyctisoma tuberculata - Glaessner 1929: 314. - Förster 1966: 145, pl. 18, fig. 11-12.

Enoploclytia tuberculata - Woods 1931: 82, pl. 23, fig. 4-8.

Eryma tuberculata - Woods 1957: 156.

Pustulina tuberculata - Schweitzer et al. 2010: 26.

TYPE MATERIAL. - Lectotype SM B22368 designated by Förster (1966); 7 paralectotypes SM B22364, B22365, B22366, B22367, B22369, B22370, B22371 (Carter coll.).

TyPE LOCALITY. - Cambridge, Cambridgeshire, United Kingdom.

TYPE AGE. - Albian, Early Cretaceous. 
DESCRIPTION. - Subcylindrical carapace (lectotype: $\mathrm{CL}=52 \mathrm{~mm}, \mathrm{CL}=24 \mathrm{~mm}$ ); fusiform, tuberculate intercalated plate; inflated cardiac, hepatic and branchial regions; deep, inclined cervical groove, joined to dorsal margin and to antennal groove; deep antennal groove, strongly curved; long gastro-orbital groove, originating as a slight median inflexion of cervical groove, with two divergent branches delimiting two gastroorbital lobes (inflated lower lobe, flat upper lobe); wide postcervical groove, strongly inclined, inflected at carapace mid-height, not joined to dorsal margin, joined to hepatic groove; shallow, short branchiocardiac groove, joined to dorsal margin, not joined to postcervical groove; concave hepatic groove, narrow, joined to cervical groove; deep inferior groove; shallow, narrow cardiac groove, straight, rising from postcervical groove, slightly inclined forward, joined to dorsal margin; carapace uniformly covered with rounded tubercles, small tubercles are between coarse tubercles; cephalic region with a row of tubercles subparallel to intercalated plate, an oblique row of tubercles in gastric region, a convex antennal row of tubercles with antennal spine; pleonal somites poorly preserved; terga with two pairs of dorsal tubercles; pleura with rounded ventral margins, covered by small tubercles; telson and uropods poorly preserved; chelate P1; short P1 propodus, almost longer than wide, covered with rounded and coarse tubercles; P1 carpus with rounded and coarse tubercles; P1 merus poorly preserved.

Remarks. - Pustulina tuberculata is close to Pustulina spinulata from Madagascar. The latter is only distinguished by its more prominent lower gastro-orbital lobe, its more inflated hepatic region and its denser tuberculation.

\section{Genus Tethysastacus $\mathrm{n}$. gen.}

(Fig. 1M)

Etymology. - A combination of Tethys, the vast Mesozoic ocean, and the Latin astacus ("marine crayfish" or "escrevisse" in Old French).

TYPE SPECIES. - Eryma tithonia Van Straelen, 1936, by monotypy.

DiAgNOSIS. - Fusiform intercalated plate; straight ocular incision; wide post-orbital area; wide and deep cervical groove; no gastro-orbital groove; wide postcervical groove, straight, strongly inclined, joined to hepatic groove; concave hepatic groove, joined to cervical groove; dense heterogeneous ornamentation, branchial region with small tubercles and small depression, gastric region with pits, frontal region with strong tubercles and pits.

DisCUSSION. - Tethysastacus n. gen. is assigned to the Erymidae based on the presence of the intercalated plate. It differs from all other erymid genera of erymid lobsters by its extremely simple carapace groove pattern and the absence of branchiocardiac and 
gastro-orbital grooves. The postcervical groove is straight, whereas it is inflected in all other genera.

Tethysastacus tithonius (Van Straelen, 1936) n. comb.

(Fig. 10A-D)

Eryma tithonia Van Straelen, 1936: 8-9, pl. 2, fig. 1-2.

Eryma tithonia - Roger 1946: 42. — Secrétan 1964: 68. — Förster 1966: 123. — Feldmann \& Titus 2006: 64.

Eryma tithonium - Schweitzer et al. 2010: 25.

TYPE MATERIAL. — Holotype MNHN.F.J03351.

TyPE LOCALITY. - Laciterne-Boisset near Moulès-et-Baucels, Hérault department, Languedoc-Roussillon region, South France.

TYPE AGE. — Valanginian, Early Cretaceous.

DESCRIPTION. - Subrectangular carapace in lateral view (holotype: $\mathrm{CL}=21 \mathrm{~mm} ; \mathrm{CH}=$ $10 \mathrm{~mm}$ ); long, toothless rostrum; intercalated plate present; short, oblique ridge near rostrum basis; straight ocular incision; wide tuberculate post-orbital area; wide, deep cervical groove, probably joined to dorsal margin, joined to antennal groove; antennal groove shallower than cervical groove, reaching post-orbital area; gastro-orbital groove absent; straight, oblique postcervical groove, as wide and deep as cervical groove, joined to hepatic groove; slightly concave hepatic groove, narrower than cervical and postcervical grooves, joined to cervical groove; curved inferior groove, joined to ventral margin behind its junction to hepatic groove, as wide and deep as hepatic groove; branchial, cardiac and hepatic regions with small tubercles intercalated with deep circular pits; similar ornamentation in pterygostomial region but with smaller and shallower pits; cephalic region with heterogeneous ornamentation: gastric region with circular pits, frontal region with strong tubercles and small pits; dense ornamentation on the whole carapace.

COMMENTS. - The holotype presents a carapace in butterfly-like position with a strong dorsoventral flattening along the dorsal midline (Fig. 10A). This mode of preservation is characteristic of a lobster molt (Glaessner 1969; Charbonnier et al. 2012b). A pronounced rupture of the dorsal midline is observed with a strong rotation of the two halves of carapace. This suggest a probable hinge-type opening during the ecdysis (Charbonnier et al. 2012b).

\section{CONCLUSIONS}


The present study expands our knowledge on the biodiversity of erymid lobsters from the Early Cretaceous. Based on our research, the known diversity of erymid lobsters during the Early Cretaceous is four species of Eryma (E. glaessneri, E. nippon, E. sulcatum, E. vocontii n. sp.), three species of Enoploclytia (E. augustobonae n. sp., E. gigantea n. sp., E. wintoni), six species of Palaeastacus (P. foersteri, P. loryi n. comb., P. sussexiensis, P. tenuidigitatus, $P$. terraereginae, $P$. walkeri), five species of Pustulina (P. colossea n. sp., P. occitana n. sp., P. victori n. n., P. spinulata, P. tuberculata), one species of Stenodactylina (S. delphinensis n. comb.), and one species of Tethysastacus n. gen. (T. tithonius n. comb.). The re-examination of old material and of new material belonging to these twenty species has allowed us to precise the generic diagnoses of five genera (Eryma, Enoploclytia, Palaeastacus, Pustulina, Stenodactylina) and to create a new genus (Tethysastacus n. gen.), mainly based on the carapace groove pattern.

The post-orbital area is identified in different species among different genera (Eryma sulcatum, Stenodactylina delphinensis, Palaeastacus foersteri, Tethysastacus tithonius). This complex structure is not present in all other species of Eryma, Palaeastacus and Stenodactylina and its evolutionary significance is questionable. It may be a case of convergence or a persistent ancestral trait conserved in only some species. Only further investigations on all erymid species showing this character will provide answers to these questions.

The description of two new species associated to the revision of several fragments of crustaceans which are now not considered to belong to erymid lobsters conduct to modify the stratigraphic range of Eryma and Enoploclytia. Eryma vocontii n. sp. extends the stratigraphic range of Eryma to the Albian and is now the youngest occurrence of Eryma. Enoploclytia augustobonae n. sp. extends the stratigraphic range of Enoploclytia from the Maastrichtian to the Barremian; it is the oldest occurrence for the genus Enoploclytia.

Finally, this work indirectly emphasizes that the Early Cretaceous erymid fauna is only known by a limited number of fragmentary fossils reported around the world. Almost $45 \%$ of the Early Cretaceous species of erymid lobsters come from France and most of them were collected in the South-East Basin, including the Vocontian Basin and its peripheral platforms.

In conclusion, our knowledge of these decapod crustaceans remains superficial and the present study highlights that new data are essential to understand the evolutionary history of the whole group.

\section{ACKNOWLEDGEMENTS}

We wish to thank Claire Mellish (Natural History Museum, London, United Kingdom), Fabienne Giraud-Guillot (Université Joseph Fournier - Institut Dolomieu, Grenoble, France), Liz Harper and Matt Riley (Sedgwyck Museum, Cambridge, United Kingdom), Lee Ismail and John Cooper (Booth Museum, Brighton, United Kingdom) 
for the access to the collections of their respective institutions. We are also grateful to Hilary Blagbrough (British Antarctic Survey, Cambridge, United Kingdom), Lionel Cavin and Pierre-Alain Proz (Natural History Museum, Geneva, Switzerland) and the volunteers of the Natural History Museum of Chambéry for searching and supplying photographs of the specimens stored in the collections of their institutions. We also really thank Jean-Michel Pacaud (MNHN, Paris, France), for helping to solve some nomenclatural complications and Lilian Cazes (MNHN, Paris, France) for the photographs of the specimens. Lucien Leroy wishes to thank particularly Myette Guiomar (Réserve Naturelle géologique de Haute-Provence) for the permission to collect fossils.

Finally, we wish to acknowledge Günter Schweigert and Alessandro Garassino for their useful comments on our manuscript which greatly improved our original manuscript. This paper is a contribution to the UMR 7207 CR2P, CNRS-MNHN-UPMC and to the Département Histoire de la Terre (Muséum national d'Histoire naturelle, Paris).

\section{REFERENCES}

ADKINS W. S. 1928. - Handbook of Texas Cretaceous fossils. University of Texas Bulletin 2838: 5-385.

Aguirre-Urreta M. B. 1982. - Crustaceos Decapodos Barremianos de la region del Tucu-Tucu, Provincia de Santa Cruz. Revista de la Asociación Paleontológica Argentina 19 (3-4): 303-317.

Aguirre-Urreta M. B. 1989. - The Cretaceous decapod Crustacea of Argentina and the Antarctic Peninsula. Palaeontology 32 (3): 499-552.

Aguirre-Urreta M. B. \& Ramos V. A. 1981. - Crustaceos Decapodos del Cretacico Inferior de la Cuenca Austral, Provincia de Santa Cruz, Argentina. Comité Sudamericano del Jurásico y Cretácico: Cuencas sedimentarias del Jurásico y Cretácico de América del Sur 2: 599-623.

Arnaud-Vanneau A., Arnaud H., Cotillon P., Ferry S. \& Masse J.-P. 1982. — Caractères et évolution des plates-formes carbonatées périvocontiennes au Crétacé Inférieur (France Sud-Est). Cretaceous Research 3: 3-18.

BACHMAYER F. 1959. - Neue Crustaceen aus dem Jura von Stramberg (ČSR). Sitzungsberichte der Österreichischen Akademie der Wissenschaften, mathematisch-naturwissenschaftliche Klasse, Abteilung 1. Biologie, Mineralogie, Erdkunde, und verwandte Wissenschaften 168: 937-944.

Bell T. 1850. - Notes on the Crustacea of the Chalk Formation, in DiXON F. (ed.), The Geology and Fossils of the Tertiary and Cretaceous Formations of Sussex. Longman, Brown, Green and Longmans, London: 344-345.

Bell T. 1863. - Crustacea of the Gault and Greensand, A monograph of the fossil malacostracous Crustacea of Great Britain, Part II. Palaeontographical Society Monograph, London, $40 \mathrm{p}$.

Beurlen K. 1928. - Die Decapoden des Schwäbischen Jura mit Ausnahme der aus den oberjurassischen Plattenkalken stammenden. Palaeontographica 70: 115-278. 
BISHOP G. A. 1986. - Taphonomy of the North American Decapods. Journal of Crustacean Biology 6 (3): 326-355.

Bravi S., Garassino A., Bartiromo A., Audo D., Charbonnier S., Schweigert G., ThÉVEnARD F. \& Longobardi C. 2014. - Middle Jurassic Monte Fallano Plattenkalke (Campania, southern Italy): first report on terrestrial plants, decapod crustaceans and fishes. Neues Jahrbuch für Geologie und Paläontologie Abhandlungen 272 (1): 79-107.

BronN H. G. (1851-1852). - Vierte Periode. Kreide-Gebirge, in H. G. BronN \& F. RoEMER, Eds., Lethaea Geognostica oder Abbildung und Beschreibung der für die Gebirgs-formationen bezeichendstein Versteinerungen, part. 4. - E. Schweitzerbart, Stuttgart, $412 \mathrm{p}$.

Charbonnier S., Audo D., GARAssino A. \& HyŽNÝ M. in press. - Fossil Crustacea of Lebanon. Mémoires du Muséum national d'Histoire naturelle.

Charbonnier S., Audo D., Barriel V., Garassino A., Schweigert G. \& Simpson M. 2015. - Phylogeny of fossil and extant glypheid and litogastrid lobsters (Crustacea, Decapoda) as revealed by morphological characters. Cladistics 31: 231249.

Charbonnier S., Garassino A. \& Pasini, G. 2012a. - Revision of Mesozoic decapod crustaceans from Madagascar. Geodiversitas 34 (2): 313-357.

Charbonnier S., Garassino A., Schweigert G. \& Simpson M. 2013. — A worldwide review of fossil and extant glypheid and litogastrid lobsters (Crustacea, Decapoda, Glypheoidea). Mémoires du Muséum national d'Histoire naturelle 205, 304 p.

Charbonnier S., PÉrès D. \& Letenneur C. 2012b. - Exceptionally preserved crustaceans from the Oxfordian of eastern France (Terrain à Chailles Formation, Haute-Saône). Geodiversitas 34 (3): 531-568.

CRÔNIER C. \& Courville P. 2004. - A rich and highly endemic decapod crustacean fauna from the Middle Jurassic of north-east France. Palaeontology 47 (4): 9991014.

De Grave S., Pontcheff N. D., Ahyong S. T., Chan T.-Y., Crandall K. A., Dworschak P. C., Felder D. L., Feldmann R. M., Fransen C. H. M., Goulding L. Y. D., Lemaitre R., Low M. E. Y., Martin J. W., NG P. K. L., Schweitzer C. E., TAN S. H., ThSudy D. \& WetZer R. 2009. - A classification of living and fossil genera of decapod crustaceans. The Raffles Bulletin of Zoology, supplement 21: 1-109.

DuMORTIER E. 1867. - Études paléontologique sur les dépôts jurassiques du Bassin du Rhône, deuxième partie, Lias Inférieur. F. Savy, Paris, 252 p.

ÉtAllon A. 1861. - Notes sur les crustacés jurassiques du bassin du Jura. Recueil agronomique, industriel et scientifique publié par la Société d'Agriculture de la Haute-Saône 9: 129-171.

ETHERIDGE JR. R. 1914. - The genus Enoploclytia in the Cretaceous rocks of Queensland. Records of the Australian Museum 10: 271-273.

Feldmann R. M. \& Haggart J. W. 2007. - A new species of lobster (Astacidea, Erymidae) from the Smithers Formation (Middle Jurassic) of British Columbia, Canada. Canadian Journal of Earth Sciences 44: 1791-1796. 
Feldmann R. M. \& MCPherson C. B. 1980. - Fossil decapod crustaceans of Canada. Geological Survey of Canada Paper 79-16: 1-20.

Feldmann R. M., Schweitzer C. E. \& Karasawa H. 2015. - Crustacea, in SElden P. A. (ed.), Treatise online, Part R (Revised), Arthropoda 4 (1), Chapter 8I: 1-28.

Feldmann R. M. \& Titus A. L. 2006. - Eryma jungostrix n.sp. (Decapoda; Erymidae) from the Redwater Shale of the Stump Formation (Jurassic; Oxfordian) of Utah. Journal of Crustacean Biology 26 (1): 63-68.

Fletcher B. N. 1969. - A lithological subdivision of the Speeton Clay C Beds (Hauterivian), East Yorkshire. Proceedings of the Yorkshire Geological Society 37: 323-327.

FÖRSTER R. 1966. - Über die Erymiden, eine alte konservative Familie der mesozoischen Dekapoden. Palaeontographica A125 (4-6): 61-175.

FöRSTER R. \& RIEBER H. 1982. - Der älteste Vertreter der Gattung Palaeastacus (Crustacea, Decapoda), Palaeastacus argoviensis n. sp., aus dem unteren Dogger der Nordschweiz. Eclogae geologicae Helvetiae 75 (3): 773-778.

FÖRSTER R. \& SEYED-EMANI K. 1982. - First occurrence of Eryma bedelta (QuenstedT) (Crustacea, Decapoda) from the Aalenian of Iran. Mitteilungen der Bayerischen Staatssammlung für Paläontologie und Historische Geologie 22: 4145.

FrIÈS G. \& PARIZE O. 2003. - Anatomy of ancient passive margin slope systems: Aptian gravity-driven deposition on the Vocontian palaeomargin, western Alps, south-east France. Sedimentology 50: 1231-1270.

FRITSCH A. \& KAFKA J. 1887. — Die Crustaceen der Böhmischen Kreideformation. Prague, $53 \mathrm{p}$.

GARASSINO A. 1994. - The macruran decapod crustaceans of the Upper Cretaceous of Lebanon. Paleontologia Lombarda, nuova serie 3: 1-27.

GARASSINO A. 1996. - The family Erymidae Van Straelen, 1924 and the superfamily Glypheoidea Zittel, 1885 in the Sinemurian of Osteno in Lombardy (Crustacea, Decapoda). Atti della Società italiana di Scienze naturali e del Museo civico di Storia natural in Milano 135: 333-373.

Garassino A., ARTAL P. \& PASINI G. 2009. - New records of decapod macrurans from the Cretaceous of Catalonia and the Province of Castellón (Spain). Bulletin of the Mizunami Fossil Museum 35: 87-95.

GARASsino A. \& Krobicki M. 2002. - Galicia marianae n. gen., n. sp. (Crustacea, Decapoda, Astacidea) from the Oxfordian (Upper Jurassic) of the Southern Polish Uplands. Bulletin of the Mizunami Fossil Museum 29: 51-59.

Garassino A. \& Schweigert G. 2006. - The Upper Jurassic Solnhofen decapod crustacean fauna: review of the types from old descriptions. Part I. Infraorders Astacidea, Thalassinidea and Palinura. Memorie della Società italiana di Scienze naturali e del Museo civico di Storia naturale di Milano 34 (1): 1-64.

GEINITZ H. B. 1875. - Das Elbthalgebirge in Sachsen. Palaeontographica 20: 1-320.

Glaessner M. F. 1929. - Crustacea Decapoda, in PomPecku J. F. (ed.), Fossilium Catalogus, I: Animalia, Pars 41: 1-464. 
GlaesSNER M. F. 1931. - Eine Crustaceenfauna aus den Lunzer Schichten Niederösterreichs. Jahrbuch der Geologischen Bundesanstalt 81 (3-4): 467-486.

Glaessner M. F. 1969. - Decapoda, in Moore R. C. (ed.), Treatise on Invertebrate Paleontology, Part R, Arthropoda 4 (2): 399-533.

HARBorT E. 1905. - Die Fauna der Schaumburg-Lippechden Kreidemulde. Abhandlungen der Preussischen Geologischen Landesanstalt, Neue Folge 45: 1022.

HyžNÝ M., Schlögl J., Charbonnier S., Schweigert G., Rulleau L. \& GOUTTENOIRE M. 2015. - Intraspecific variation and taphonomy of a new erymid lobster (Crustacea: Decapoda) from the Middle Jurassic of Belmont (Beaujolais, France). Geobios 48: 371-384.

ICZN 1999. - International Code of Zoological Nomenclature. International Trust for Zoological Nomenclature. The Natural Museum, London, v-xxix, 1-306.

Jagt W. M. \& FraAiJe R. H. B. 2002. - The erymid lobster Enoploclytia leachii (MANTEll, 1822) from the Upper Campanian of northeast Belgium. Bulletin de l'Institut royal des sciences naturelles de Belgique, Sciences de la Terre 72: 91-95.

Joleaud L. \& Hsu T.-Y. 1935. - Crustacés décapodes du Crétacé de Tanout (Damergou, Niger français). Archives du Muséum national d'Histoire naturelle 13 (6): 99-110.

Karasawa H., Ohara M. \& Kato H. 2008. - New records for Crustacea from the Arida Formation (Lower Cretaceous, Barremian) of Japan. Boletín de la Sociedad Geológica Mexicana 60 (1): 101-110.

Karasawa H., Schweitzer C. E. \& Feldmann R. M. 2013. - Phylogeny and Systematics of extant and extinct lobsters. Journal of Crustacean Biology 33 (1): 78-123.

Krause H. P. G. 1891. - Die Decapoden des norddeutschen Jura. Zeitschrift der Deutschen geologischen Gesellschaft 43: 171-225.

Krause JR. R. A., Parsons-Hubbard K. \& Walker S. E. 2011. - Experimental taphonomy of a decapod crustacea: Long-term data and their implications. Palaeogeography, Palaeoclimatology, Palaeoecology 312: 350-362.

LAHUSEN J. 1894. - Über die russischen Krebsreste aus den jurassischen Ablagerungen und derunteren Wolgastufe. Verhandlungen der Russischen Kaiserlichen Mineralogischen Gesellschaft 31 (2): 313-324.

Latreille P. A. 1802. - Histoire Naturelle, Générale et Particulière des Crustacés et des Insectes. Tome 3. F. Dufart, Paris, 468 p.

Mantell G. A. 1822. - The Fossil of the South Downs; or Illustrations of the Geology of Sussex. Lupton Relfe, London, 327 p.

Mantell G. A. 1824. - Outlines of the natural history, of the environs of Lewes, in Horsfield T. W. (ed.), The History and antiquities of Lewes and its vicinity. J. Baxter, Lewes, 344 p.

Mantell G. A. 1833. - The Geology of the South-East of England. Longman, Rees, Orme, Brow, Green \& Longman, London, 415p.

Mantell G. A. 1844. - The Medals of Creation; or, First Lessons in Geology and in the Study of Organic Remains, Volume II. Henry G. Bohn, London: 459-1016. 
Masse J.-P., Bellion Y., Benkhelil J., Boulin J., Cornée J. J., Dercourt J., Guiraud R., Mascle G., Poisson A., Ricou L. E. \& Sandulescu M. 1993. Lower Aptian, in Dercourt J., Ricou L. E. \& Vrielynck B. (eds.), Atlas Tethys Palaeoenvironmental Maps. CCGM, Paris.

M'Coy F., 1849. - On the classification of some British Fossil Crustacea, with Notices of new Forms in the University Collection at Cambridge. Annals and Magazine of Natural History, including Zoology, Botany, and Geology 4 (2): 330-335.

M'Coy F., 1854. - Contributions to British Palaeontology, or first descriptions of three hundred and sixty species and several genera of fossil Radiata, Articulata, Mollusca, and Pisces from the Tertiary, Cretaceous, Oolitic, and Palaeozoic strata of Great Britain. Macmillan and co., Cambridge, 272 p.

Merill G. P. 1905. - Catalogue of the Type and Figured Specimens of Fossils, Minerals, Rocks and Ores in the Department of Geology, United States National Museum, Part I, Fossil Invertbrates. Bulletin of the United States National Museum 53: $1-704$.

Mertin H. 1941. - Decapode Krebse aus dem subhercynen und Braunschweiger Emscher und Untersenon. Nova Acta Leopoldina 68 (10): 149-264.

MEYer H. VON 1840a. — Briefliche Mittheilungen. Neues Jahrbuch für Mineralogie, Geognosie, Geologie und Petrefactenkunde: 576-587.

MeYer H. vON 1840b. - Neue Gattungen fossiler Krebse aus Gebilden vom bunten Sandstein bis in die Kreide. E. Schweizerbart'sche Verlagshandlung, Stuttgart, 28 p.

MiLne EdWARds H. 1834. - Histoire Naturelle des Crustacés, comprenant l'anatomie, la physiologie et la classification de ces animaux, Tome 1. Roret, Paris, $468 \mathrm{p}$.

Monaco P. \& GARAssino A. 2000. - Burrows and body fossil of decapod crustaceans in the Calcari Grigi, Lower Jurassic, Trento Platform (Italy). Geobios 34 (3): 291301.

MORET L. 1946. - Eryma delphinensis nouvelle espèce de Crustacé Décapode du Berriasien de Noyarey (Isère). Travaux du Laboratoire de Géologie, Faculté des sciences de Grenoble 25: 49-51.

MORIERE J. 1883. - Note sur quelques crustacés fossiles. Bulletin de la Société linnéenne de Normandie 4 (2): 136-143.

MORRIS J. 1854. - A catalogue of British Fossils: comprising the genera and species hitherto described; with references to their geological distribution and to the localities in which they have been found. Second edition. J. Morris, London, $372 \mathrm{p}$.

Morris S. F. 1980. - Catalogue of the Type and Figured Specimens of Fossil Crustacea (excl. Ostracoda), Chelicerata, Myriapoda and Pycnogonida in the British Museum (Natural History). Trustees of the British Museum (Natural History), London, $53 \mathrm{p}$.

Morris S. F. 1987. - Arthropods, in SMITH A. B. (ed.), Fossils of the Chalk. The Palaeontological Association, London, $306 \mathrm{p}$.

Müller P., Krobicki M. \& Wehner G. 2000. - Jurassic and Cretaceous primitive crabs of the family Prosopidae (Decapoda: Brachyura) - their taxonomy, ecology and biogeography. Annales Societatis Geologorum Poloniae 70: 49-79. 
Mutel M. H. E., Waugh D. A., Feldmann R. M. \& Parsosn-Hubbard K. M. 2008. Experimental taphonomy of Callinectes sapidus and cuticular controls on preservation. Palaios 23: 615-623.

Oppel A. 1861. - Die Arten der Gattungen Eryma, Pseudastacus, Magila und Etallonia. Jahreshefte des Vereins für Vaterländische Naturkunde in Württemberg 17: 355-361.

OPPEL A. 1862. - Ueber jurassische Crustaceen (Decapoda macrura). Palaeontologische Mittheilungen aus dem Museum des koeniglich Bayerischen Staates 1: 1-120.

PlotNiCK R. E. 1986. - Taphonomy of a Modern Shrimp: Implications for the Arthropod Fossil Record. Palaios 1 (3): 286-293.

Plotnick R. E., BAumiller T., Wetmore K. L. 1988. - Fossilization potential of the mud crab, Panopeus (Brachyura: Xanthidae) and temporal variability in crustacean taphonomy. Palaeogeography, Palaeoclimatology, Palaeoecology 63: 27-43.

Quenstedt F. A. 1852. — Handbuch der Petrefaktenkunde. H. Laupp, Tübingen, 792 p.

QuenstedT F. A. 1856-1857. — Der Jura. H. Laupp, Tübingen, 842 p.

Rathbun M. J. 1923. - Decapod Crustaceans from the Upper Cretaceous of North Carolina. North Carolina Geological and Economic Survey 5: 403-408.

Rathbun M. J. 1926. - Arthropoda, in WADE B. (ed.), The Fauna of the Ripley Formation on Coon Creek, Tennessee. Professional Paper 137: 184-191.

Rathbun M. J. 1935. - Fossil Crustacea of the Atlantic and Gulf Coastal Plain. Geological Society of America Special Papers 2: 1-160.

Reuss A. E. 1854. - Über Klytia Leachi, einen langschwänzigen Decapoden der Kreideformation. Denkschriften der kaiserlichen Akademie der Wissenschaften 6: $1-10$.

RichARDSON JR. E. S. 1955. - A New Variety of Cretaceous Decapod from Texas. Fieldana: Zoology 37: 445-448.

ROBERTS H. B. 1962. - The Upper Cretaceous decapod crustaceans of New Jersey and Delaware, in Cooke C. W., Garner H. F., Howell B. F., Jeletzky J. A., Miller A. K., Miller JR. H. W., Ramsdell R. C., Richards H. G., Reeseide Jr. J. B., Roberts H. B. \& Wells J. W. (eds.), The Cretaceous Fossils of New Jersey. Geological Survey of New Jersey Bulletin 61 (2): 163-191.

Robineau-Desvoidy J.-B. 1849. - Mémoire sur les crustacés du terrain Néocomien de Saint-Sauveur-en-Puisaye (Yonne). Annales de la Société Entomologique de France 7: 95-141.

RoEMER F. A. 1841. - Die Versteinerungen des norddeutschen Kreidegebirges. Hahn, Hannover, $145 \mathrm{p}$.

Roger J. 1946. — Les invertébrés des couches à poisons du Crétacé supérieur du Liban. Mémoires de la Société Géologique de France 51: 1-92.

Savostin L. A., Sibuet J.-C., Zonenshain L. P., Le Pichon X. \& Roulet M.-J. 1986. - Kinematic evolution of the Tethys belt from the Atlantic ocean to the Pamirs since the Triassic. Tectonophysics 123: 1-35.

SCHLOTHEIM E. F. VON 1822. - Beiträge zur näheren Bestimmung der versteinerten und fossilen Krebsarten. Nachträge zur Petrefaktenkunde. Becker, Gotha: 17-37. 
SCHLÜTER H. 1879. - Neue und weniger bekannte Kreide- und Tertiär-Krebse des nördlichen Deutschlands. Zeitschrift der Deutschen geologischen Gesellschaft 31: 586-615.

SCHRAM F. R. \& DiXON C. J. 2004. — Decapod phylogeny: addition of fossil evidence to a robust morphological cladistics data set. Bulletin of the Mizunami Fossil Museum 31: 1-19.

SCHWEIGERT G. 2013. - A new record of the enigmatic lobster genus Stenodactylina Beurlen, 1928 (Crustacea: Decapoda: Erymidae) from the Middle Jurassic of southwestern Germany. Paläontologische Zeitschrift 87: 409-413.

Schweigert G., Dietl G. \& RöPer M. 2000. — Die Panzerkrebse des Familie Erymidae VAN STRAELEN (Crustacea, Decapoda) aus dem Nusplinger Plattenkalk (Ober-Kimmeridgium, Schwäbische Alb) im Vergleich mit fränkischen Vorkommen. Stuttgarter Beiträge zur Naturkunde B (285): 1-25.

Schweigert, G. \& GARAssino, A. 2003. - New studies of decapod crustaceans from the Upper Jurassic lithographic limestones of southern Germany. Contributions to Zoology 72: 173-179.

Schweitzer C. E., Feldmann R. M., Garassino A., Karasawa H. \& Schweigert G. 2010. - Systematic list of fossil decapod crustacean species. Crustaceana Monographs 10: 1-222.

Schweitzer C. E. \& Feldmann R. M. 2001. - New Cretaceous and Tertiary decapod crustaceans from western North America. Bulletin of Mizunami Fossil Museum 28: 173-210.

SECRETAN S. 1964. — Les Crustacés décapodes du Jurassique supérieur et du Crétacé de Madagascar. Mémoires du Muséum national d'Histoire naturelle, Nouvelle série, Série C, Sciences de la Terre 14: 1-226.

SECRETAn S. 1984. - Présence d'Eryma bedelta (Crustacea Decapoda) dans le Bajocien du Maroc oriental. Geobios 17 (4): 515-518.

STEMPIEN J. A. 2005. - Brachyuran taphonomy in a modern tidal-flat environment: preservation potential and anatomical bias. Palaios 20: 400-410.

Stenzel H. B. 1945. - Decapod Crustacea from the Cretaceous of Texas. Texas University Publications 4401: 401-476.

TAYLOR B. J. 1979. - Macrurous Decapoda from the Lower Cretaceous of SouthEastern Alexander Island. British Antarctic Survey Scientific Reports 81: 1-39.

Tshudy D. M., Feldmann R. M. \& WARD P. D. 1989. - Cephalopods; biasing agents in the preservation of lobsters. Journal of Paleontology 63 (5): 621-626.

VAN STRAELEN V. 1923. - Description de Crustacé décapodes macroures nouveaux des terrains secondaires. Annales de la Société royale zoologique de Belgique 53: 8493.

VAn Straelen V. 1925. - Contribution à l'étude des crustacés décapodes de la période jurassique. Mémoires de la Classe des Sciences de l'Académie royale de Belgique 7: 1-462.

VAN STRAELEN V. 1936. - Crustacés décapodes nouveaux ou peu connus de l'époque crétacique. Bulletin du Musée royal d'Histoire naturelle de Belgique 12 (45): 1-50. 
Vega F. J., Garassino A. \& Jaime R. Z. 2013. - Enoploclytia tepeyacensis n. sp. (Crustacea, Decapoda, Erymidae) from the Cretaceous (Campanian) of Coahuila, NE Mexico. Boletín de la Sociedad Geológica Mexicana 65 (2): 207-211.

Wahle R. A., Thsudy D., CobB J. S., FACTOR J. \& JAINi M. 2012. - Infraorder Astacidea Latreille, 1802 p. p.: The Marine Clawed Lobsters, in Schram F. R., Vaupel Klein J. C. von, Charmantier-Daures M. \& Forest J. (eds.) Treatise of Zoology - Anatomy, Taxonomy, Biology - The Crustacea, Volume 9, Part B, Eucarida, Astacidea P. P. (Enoplometopoidea, Nephropoidea), Glypheidea, Axiidea, Gebiidea, and Anomura. Brill, Leiden \& Boston: 3-108.

WEBER F. 1795. - Nomenclator entomologicus secundum entomologiam systematicum ill. Fabricii, adjectis speciebus recens detectis et varietatibus. Chiloni et Hamburg, Bohn, $171 \mathrm{p}$.

Whitfield R. P. 1883. - Articulata, in HAYden F. V. (ed.), Contribution to invertebrate paleontology, 2: Cretaceous fossils of the Western States and Territories. 12 $2^{\text {th }}$ Annual Report of the United States Geological and Geographical Survey of the Territories: a report of progress of the exploration in Wyoming and Idaho for the year 1878, Part I: 37-38.

WiLlet H. 1871. - Catalogue of the Cretaceous Fossils in the Brighton Museum. W. J. Smith, Brighton, $66 \mathrm{p}$.

WitTler, F. 1998. - Palaeastacus sussexiensis (Mantell) und Enoploclytia leachi (Mantell), zwei seltene Krebse aus dem Turon des Dortmunder Stadtgebietes. Arbeitskreis Paläontologie Hannover 26: 15-21.

Woods H. 1925-1931. - A Monograph of the Fossil Macrurous Crustacea of England. The Palaeontographical Society, London: 1-122.

Woods J. T. 1957. - Macrurous Decapods from the Cretaceous of Queensland. Memoirs of the Queensland Museum 13 (3): 155-175.

Woodward H. 1877. - A Catalogue of British Fossil Crustacea with their Synonyms and the range in time of each Genus and Order. Taylor and Francis, London, $155 \mathrm{p}$.

Woodward H. 1878. - Notes on the Crustacea of the Chalk Formation by Professor Thomas Bell, F.R.S. revised by Dr. Henry Woodward, in DixON F. (ed.), The geology of Sussex; or the geology and fossils of the Tertiary and Cretaceous Formations of Sussex. $2^{\text {nd }}$ edition. W. J. Smith, Brighton: 377-380.

ZitTEL K. A. VON 1885. - Handbuch der Palaeontologie 1 (2) (Arthropoda, Decapoda): 523-721. 


\section{Captions}

TABLE 1. - List of the examined material of Early Cretaceous erymid lobsters.

FIG. 1. - Line drawings of carapaces and P1 chelae of Early Cretaceous erymid lobsters from Western Europe. A-C, Eryma Meyer, 1840: carapace (A), P1 chela form I (B), P1 chela form II (C); D-F, Stenodactylina Beurlen, 1928: carapace (D), P1 chela form I (E), P1 chela form II (F); G-H, Palaeastacus Bell, 1850: carapace (G), P1 chela (H); I-J, Enoploclytia M'Coy, 1849: carapace (I), P1 chela (J); K-L, Pustulina Quenstedt, 1857: carapace (K), P1 chela (L); M, Tethysastacus n. gen.: carapace. Abbreviations: $a$ : branchiocardiac groove; $b$ : antennal groove; $b_{1}$ : hepatic groove; $c$ : postcervical groove; cd: cardiac groove; d: gastro-orbital groove; $\mathrm{e}_{1} \mathrm{e}$ : cervical groove; $\mathrm{i}$ : inferior groove; ip: intercalated plate; PoA: post-orbital area; $\omega$ : attachment site of mandibular muscle; $\chi$ : attachment site of adductor testis muscle. Line drawings: J. Devillez and S. Charbonnier.

FIG. 2. - Geographical location of French Early Cretaceous erymids with the northern boundary of the South-East Basin during the Lower Aptian (modified after Masse et al. 1993).

FIG. 3. - Anatomical terminology of erymid lobsters. A-B: holotype BAS KG.50.4 of Palaeastacus foersteri Taylor, 1979 from the Barremian of Alexander Island, Antarctic: general view (A) and line drawing of the carapace (B); C: extant lobster Homarus gammarus (Linnaeus, 1758) with P1 chelae terminology. Scale bars: $10 \mathrm{~mm}$. Abbreviations: a: branchiocardiac groove; b: antennal groove; c: postcervical groove; cam: carina of anterior margin; d: gastro-orbital groove; da: dactylus; db: dactylar bulge; ds: dorsal surface; $\mathrm{e}_{1} \mathrm{e}$ : cervical groove; i: inferior groove; im: inner margin; in: index; om: outer margin: PoA: post-orbital area; Sag: S-shaped anterior groove. Photographs: Hillary Blagbrough (A), Bart Braun (C). Line drawing: J. Devillez.

FIG. 4. - Species of Eryma Meyer, 1840 from Western Europe. A-D, holotype MNHN.F.A57457 (Clément coll.) of Eryma vocontii n. sp. from the Albian of Rosans, France: right lateral view (A), line drawing (B), left lateral (C) and dorsal (D) views; EF, paratype MNHN.F.A57458 (Clément coll.) of Eryma vocontii n. sp.: dorsal view of right P1 chela (E) and line drawing (F); G-H: cast of the holotype MNHN.F.R10204 of Eryma glaessneri (Van Straelen, 1936) from the Hauterivian of Escragnolles, France: left lateral view $(\mathrm{G})$ and line drawing $(\mathrm{H})$; I-L, neotype herein designated SM B11437 of Eryma sulcatum Harbort, 1905 from the Hauterivian of Speeton, United Kingdom: left lateral view (I), dorsal view (K) and line drawings (J, L). Scale bars: $5 \mathrm{~mm}$ for A-F; 
$10 \mathrm{~mm}$ for G-L. Abbreviations: a: branchiocardiac groove; $\mathrm{b}$ : antennal groove; $\mathrm{b}_{1}$ : hepatic groove; c: postcervical groove; d: gastro-orbital groove; $\mathrm{e}_{1} \mathrm{e}$ : cervical groove; $\mathrm{i}$ : inferior groove; ip: intercalated plate; PoA: post-orbital area; $\omega$ : attachment site of mandibular muscle; $\chi$ : attachment site of adductor testis muscle. Photographs: L. Cazes (A-D, G), J. Devillez (I, K). Line drawings: J. Devillez.

FIG. 5. - Stenodactylina delphinensis (Moret, 1946) n. comb. from the Berriasian of Noyarey, France: holotype OSUG.UJF-ID 11152. A, carapace in dorsal view showing the two sides; B, line drawing of right side. Scale bars: $5 \mathrm{~mm}$. Abbreviations: a: branchiocardiac groove; $b$ : antennal groove; $b_{1}$ : hepatic groove; $c$ : postcervical groove; d: gastro-orbital groove; e e: cervical groove; i: inferior groove; PoA: post-orbital area. Photograph: L. Cazes. Line drawing: J. Devillez.

FIG. 6. - Palaeastacus sussexiensis (Mantell, 1824) from the Cretaceous of the United Kingdom. A-B, lectotype herein designated (NHMUK 5601, Mantell coll.) from the Cenomanian of Sussex: right side of carapace with parts of pereiopods (A) and line drawing of carapace (B); C-D, paralectotype NHMUK 5624 (Mantell coll.) from the Late Cretaceous of Southerham: dorsal view of left P1 chela (C) and line drawing (D); E, syntype SM B8885 of Enoploclytia brevimana M'Coy, 1849 from the Cenomanian of Cherryhinton: dorsal view of left P1 chela; F, lectotype BM 007750 (Willet coll.) of Palaeastacus dixoni Bell, 1850 from the Cenomanian of Glynde: dorsal view. Scale bars: $10 \mathrm{~mm}$ for A-E, $20 \mathrm{~mm}$ for F. Abbreviations: a: branchiocardiac groove; b: antennal groove; $b_{1}$ : hepatic groove; $c$ : postcervical groove; $d$ : gastro-orbital groove; $\mathrm{e}_{1} \mathrm{e}$ : cervical groove; i: inferior groove. Photographs and line drawings: J. Devillez.

FIG. 7. - Palaeastacus sussexiensis (Mantell, 1824) from the United Kingdom (A-E) and Palaeastacus loryi (Van Straelen, 1923) n. comb. from France (F-G). A, syntype SM B8892 of Enoploclytia imagei M'Coy, 1849 from the Cenomanian of Maidstone: part of carapace with right P1 chelae; B-C, lectotype NHMUK 41938 of Hoploparia scabra Bell, 1863 from the Albian of Folkestone: right lateral view (B) and line drawing (C); D-E, syntype SM B22448 (Carter coll.) of Phlyctisoma granulatum Bell, 1863 from the Albian of Cambridge: right lateral view (D) and line drawing (E); F-G, holotype (probably lost) of Palaeastacus loryi from the Valanginian of Malleval: original figure of carapace by Van Straelen (1936: pl. 1, fig. 6) (C) and line drawing (D). Scale bars: $20 \mathrm{~mm}$ for A, $10 \mathrm{~mm}$ for B-G. Abbreviations: a: branchiocardiac groove; b: antennal groove; $b_{1}$ : hepatic groove; $c$ : postcervical groove; $d$ : gastro-orbital groove; $\mathrm{e}_{1} \mathrm{e}$ : cervical groove; i: inferior groove; $\omega$ : attachment site of mandibular muscle. Photographs and line drawings: J. Devillez. 
FIG. 8. - New species of Early Cretaceous Enoploclytia M'Coy, 1849. A-D, holotype MNHN.F.B14557 of Enoploclytia augustobonae n. sp. from the Barremian of Amance, France: carapace in right lateral view (A), and line drawing (B), dorsal view (C) showing the deviation of median line in cephalic region (intercalated plate) and line drawing (D); E-H, holotype of Enoploclytia gigantea n. sp. from the Albian of Fort Worth, USA: original figures of carapace by Rathbun (1935: pl. 4 figs 1-2), left lateral view (E), right lateral view (F), and line drawings (G, H). Scale bars: $10 \mathrm{~mm}$ for A-D, $20 \mathrm{~mm}$ for E-H. Abbreviations: a: branchiocardiac groove; b: antennal groove; $b_{1}$ : hepatic groove; c: postcervical groove; d: gastro-orbital groove; $\mathrm{e}_{1} \mathrm{e}$ : cervical groove; $\mathrm{i}$ : inferior groove; $\omega$ : attachment site of mandibular muscle. Photographs: L. Cazes $(\mathbf{A}, \mathbf{C})$. Line drawings: J. Devillez.

FIG. 9. - Species of Pustulina Quenstedt, 1857 from Western Europe. A-D, holotype MNHN.F.A57460 (Leroy coll.) of Pustulina occitana n. sp. from the Berriasian of Laciterne-Boisset near Moulès-et-Baucels, France: carapace in right lateral view (A), dorsal view (C) and line drawings (B, D); E-F, holotype (probably lost) of Pustulina victori nomen novum from the Berriasian of Leysse, France: original figure of carapace by Van Straelen (1936: pl. 2, fig. 3) (E) and line drawing (F); G-H, holotype MNHN.F.A57459 (Leroy coll.) of Pustulina colossea n. sp. from the Hauterivian of Castellane, France: left lateral view (G) and line drawing (H); I-L, specimen MNHN.F.A57461 of Pustulina tuberculata (Bell, 1863) from the Albian of Cambridge, United Kingdom: right lateral view (I), dorsal view (K) and line drawings (J, L). Scale bars: $10 \mathrm{~mm}$. Abbreviations: a: branchiocardiac groove; $b$ : antennal groove; $b_{1}$ : hepatic groove; c: postcervical groove; cd: cardiac groove; d: gastro-orbital groove; $\mathrm{e}_{1} \mathrm{e}$ : cervical groove; i: inferior groove. Photographs: L. Cazes (A, C, G, I, K). Line drawings: J. Devillez.

FIG. 10. - Type material of Tethysastacus n. gen. A-B; holotype MNHN.F.J03351 of Tethysastacus tithonius (Van Straelen, 1936) n. comb. from the Valanginian of Laciterne-Boisset near Moulès-et-Baucels, France: almost complete right side of carapace and cephalic region of left side of carapace (A), detail of cephalic region showing the wide post-orbital area (B), line drawing of carapace (C) close-up of cephalic region (D). Scale bars: $5 \mathrm{~mm}$. Abbreviations: b: antennal groove; $b_{1}$ : hepatic groove; c: postcervical groove; cam: carina of anterior margin; e e cervical groove; $\mathrm{i}$ : inferior groove; ip: intercalated plate; PoA: post-orbital area; Sag: S-shaped anterior groove. Photographs: L. Cazes. Line drawings: J. Devillez. 


\begin{tabular}{|c|c|c|c|c|}
\hline TAXA & EXAMINED MATERIAL & ANATOMY & AGES & LOCALITIES \\
\hline \multicolumn{5}{|l|}{ Eryma Meyer, 1840} \\
\hline Eryma babeaui Étallon, 1861 & cast of holotype MNHN.F.B13231 & P1 chela & Kimmeridgian & France \\
\hline Eryma glaessneri Van Straelen, 1936 & holotype MNHG GEPI 28369 (cast MNHN.F.R10204) & carapace & Hauterivian & France \\
\hline \multirow[t]{2}{*}{ Eryma sulcatum Harbort, 1905} & $\begin{array}{l}\text { - neotype SM B11437. } \\
\text { - casts of the type material (lost): NHMUK In.27305, In.27307, } \\
\text { In. } 27308, \text { In.27309, In.27310. }\end{array}$ & $\begin{array}{l}\text { carapaces with P1 } \\
\text { chelae and pleons }\end{array}$ & Hauterivian & $\begin{array}{l}\text { United-Kingdom } \\
\text { Germany }\end{array}$ \\
\hline & -3 additional specimens NHMUK In.27837, In.61410, In.61411. & & & United-Kingdom \\
\hline Eryma vocontii n. sp. & holotype MNHN.F.A57457, paratype MNHN.F.A57458 & $\begin{array}{l}\text { carapace and right } \\
\text { P1 chela }\end{array}$ & Albian & France \\
\hline \multicolumn{5}{|l|}{ Palaeastacus Bell, 1850} \\
\hline Palaeastacus loryi (Van Straelen, 1923) n. comb. & holotype housed in OSUG, probably lost & carapace & Valanginian & France \\
\hline Palaeastacus sussexiensis (Mantell, 1824) & $\begin{array}{l}\text { - lectotype NHMUK } 5601,13 \text { paralectotypes NHMUK } 5024 \text {, } \\
5584,5586,5589,5600,5602,5608,5613,5618,5624,5626,5629 \text {, } \\
10760 \text {. } \\
\text { - } 30 \text { additional specimens NHMUK In.27682, In.36768, I.62, } \\
\text { I.2190, I.2628, 5685, } 35124,44343,024318,02631646782,59668, \\
59824,59824 ; \text { BM } 002548,002549,007751,007752,007753, \\
007754,007755,007758,008632,008633,008635,008636, \\
008637,008659,016988,024317,024318,026316 .\end{array}$ & $\begin{array}{l}\text { carapaces, P1 chelae, } \\
\text { pleons }\end{array}$ & $\begin{array}{l}\text { Cenomanian - } \\
\text { Turonian }\end{array}$ & United-Kingdom \\
\hline \multicolumn{5}{|l|}{ junior synonyms of Palaeastacus sussexiensis } \\
\hline Enoploclytia brevimana M'Coy 1849 & 3 syntypes SM B8884, B8885, B8886 & P1 chelae & Cenomanian & United-Kingdom \\
\hline Enoploclytia imagei M'Coy 1849 & $\begin{array}{l}8 \text { syntypes SM B8892, B8893, B8894, B8895, B8896, B8897, } \\
\text { B8898, B8899 }\end{array}$ & $\begin{array}{l}\text { carapace and P1 } \\
\text { pereiopods }\end{array}$ & Cenomanian & United-Kingdom \\
\hline Hoploparia scabra Bell, 1863 partim & $\begin{array}{l}\text { - lectotype NHMUK } 41938,2 \text { paralectotypes NHMUK } 39377, \\
39380 . \\
4 \text { additional specimens NHMUK In.27684, In.61022, In.27685, } \\
\text { In. } 27686 .\end{array}$ & $\begin{array}{l}\text { carapaces and } \mathrm{P} 1 \\
\text { pereiopods }\end{array}$ & Albian & United-Kingdom \\
\hline Palaeastacus dixoni Bell, 1850 & $\begin{array}{l}\text {-lectotype BM 007750, paralectotype NHMUK I.1916. } \\
\text {-1 additionnal specimen BM } 007757 .\end{array}$ & $\begin{array}{l}\text { carapaces, P1 chelae, } \\
\text { pleon }\end{array}$ & Cenomanian & United-Kingdom \\
\hline Phlyctisoma granulatum Bell, 1863 & 2 syntypes SM B22448, B22449 & carapaces & Albian & United-Kingdom \\
\hline \multicolumn{5}{|l|}{ Pustulina Quenstedt, 1857} \\
\hline Pustulina occitana n. sp. & holotype MNHN.F.A57460 & carapace & Berriasian & France \\
\hline Pustulina victori nomen novum & holotype housed in MHNC, probably lost & carapace left side & Berriasian & France \\
\hline Pustulina colossea $\mathrm{n} . \mathrm{sp}$. & holotype MNHN.F.A57459 & carapace left side & Hauterivian & France \\
\hline Pustulina tuberculata (Bell, 1863) & $\begin{array}{l}\text { - lectotype SM B22368, } 7 \text { paralectotypes SM B22364, B22365, } \\
\text { B22366, B22367, B22369, B22370, B22371. } \\
\text { - } 3 \text { additional specimens MNHN.F.A57461, NHMUK 34732, } \\
\text { In. } 60148 \text {. }\end{array}$ & $\begin{array}{l}\text { carapaces, P1 chelae, } \\
\text { pleon }\end{array}$ & Albian & United-Kingdom \\
\hline Pustulina spinulata Secrétan, 1964 & holotype MNHN.F.R03961, 51 paratypes & carapaces, $\mathrm{P} 1$ chelae & $\begin{array}{l}\text { Valanginian - } \\
\text { Hauterivian }\end{array}$ & Madagascar \\
\hline \multicolumn{5}{|l|}{ Stenodactylina Beurlen, 1928} \\
\hline Stenodactylina armata (Secrétan, 1964) n. comb. & $\begin{array}{l}\text { holotype MNHN.F.R03913, } 3 \text { paratypes MNHN.F.A33209, } \\
\text { A33464, R03912 }\end{array}$ & Pl chelae & Campanian & Madagascar \\
\hline Stenodactylina australis (Secrétan, 1964) n. comb. & $\begin{array}{l}\text { holotype MNHN.F.R03972, } 3 \text { paratypes MNHN.F.R } 03971 \text {, } \\
\text { A31660, A33207 }\end{array}$ & P1 chelae & Tithonian & Madagascar \\
\hline Stenodactylina delphinensis (Moret, 1946) n. comb. & holotype UJF-ID 11152 & carapace & Berriasian & France \\
\hline Stenodactylina granulifera (Secrétan, 1964) n. comb. & holotype MNHN.F.R03975, 1 paratype MNHN.F.R3974 & carapace & Kimmeridgian & Madagascar \\
\hline Stenodactylina insignis (Oppel, 1862) n. comb. & holotype MNHN.F.A24613 & P1 chela & Oxfordien & France \\
\hline \multicolumn{5}{|l|}{ Tethysastacus n. gen. } \\
\hline Tethysastacus tithonius (Van Straelen, 1936) n. comb. & holotype MNHN.F.J03351 & carapace & Valanginian & France \\
\hline
\end{tabular}




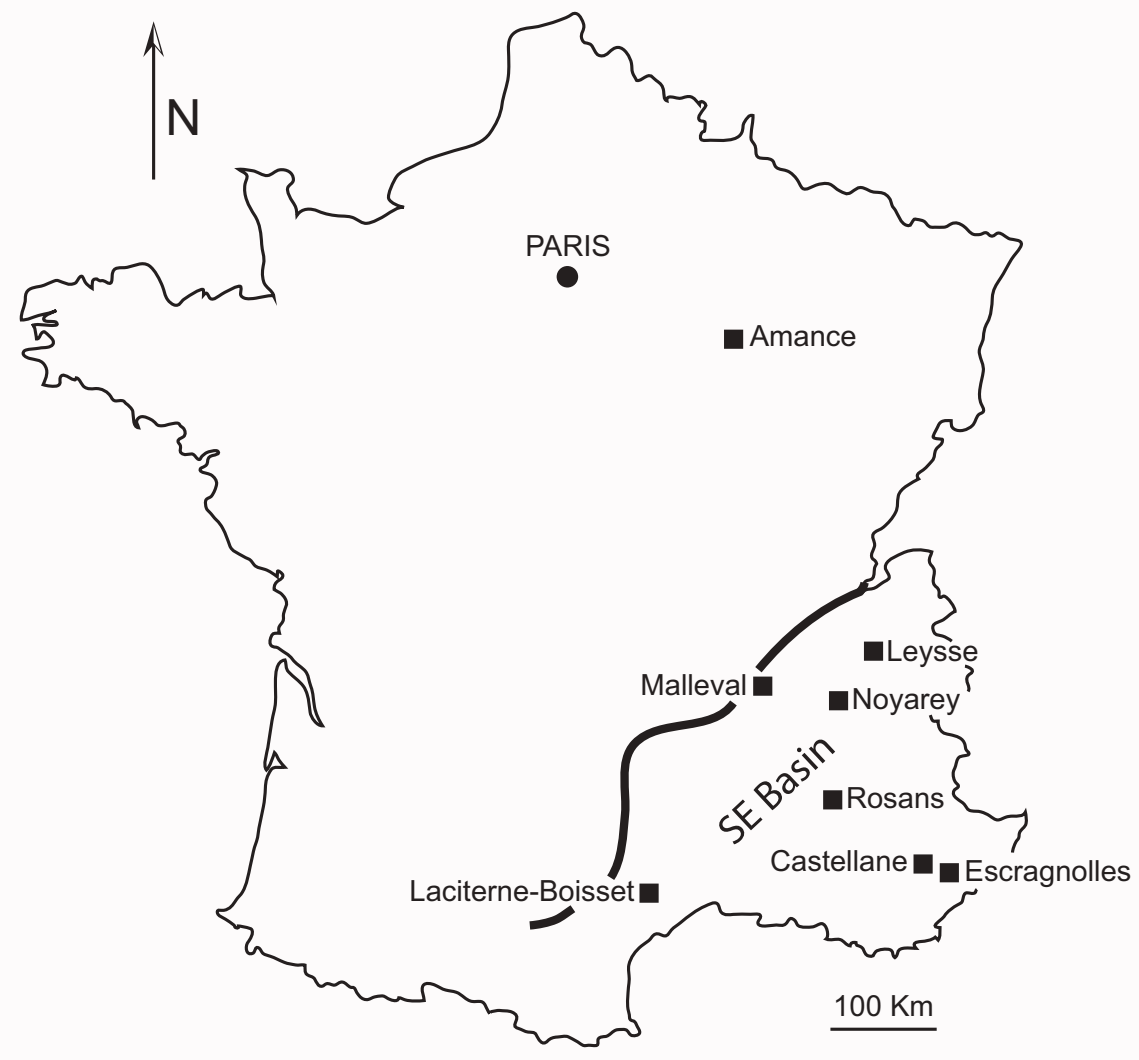




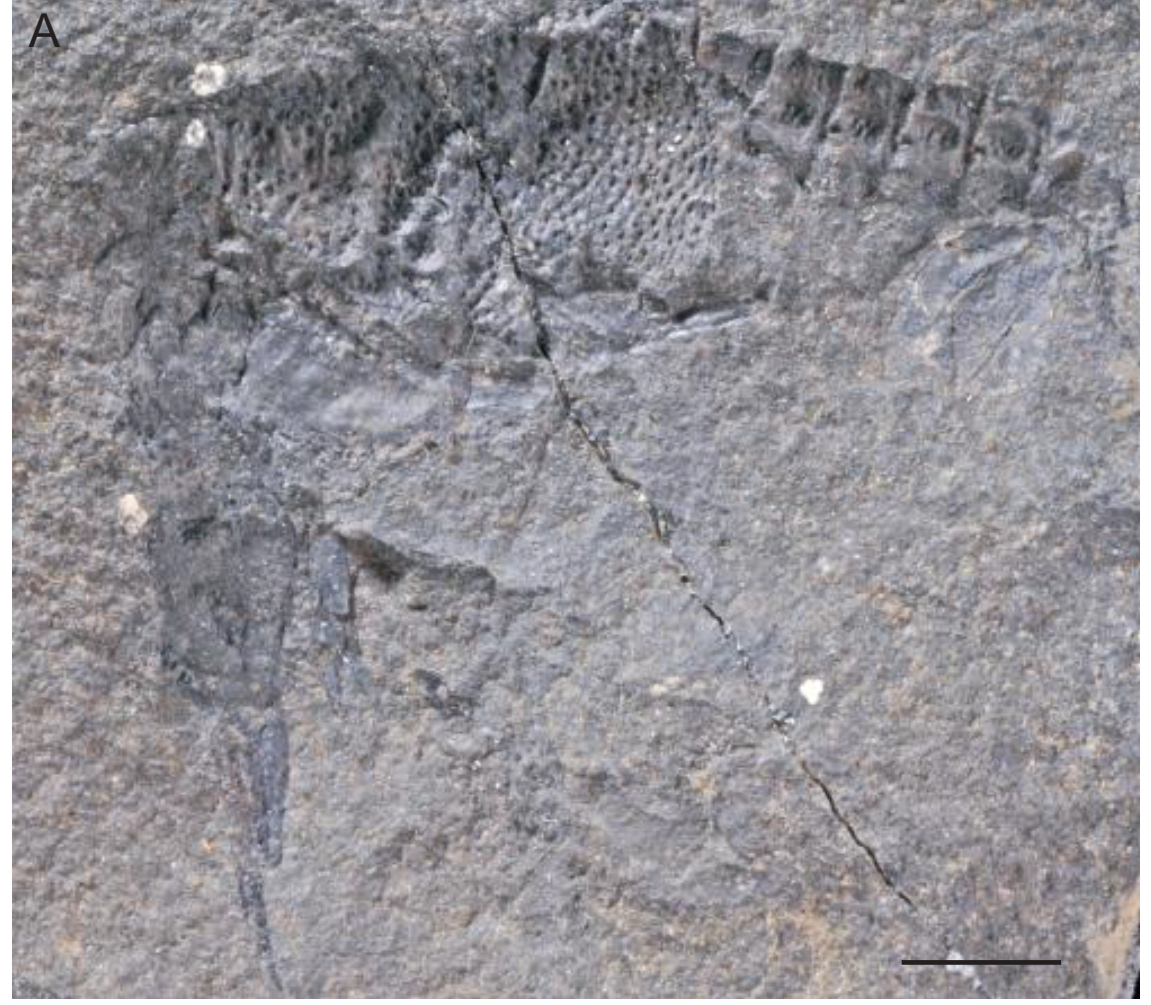

B
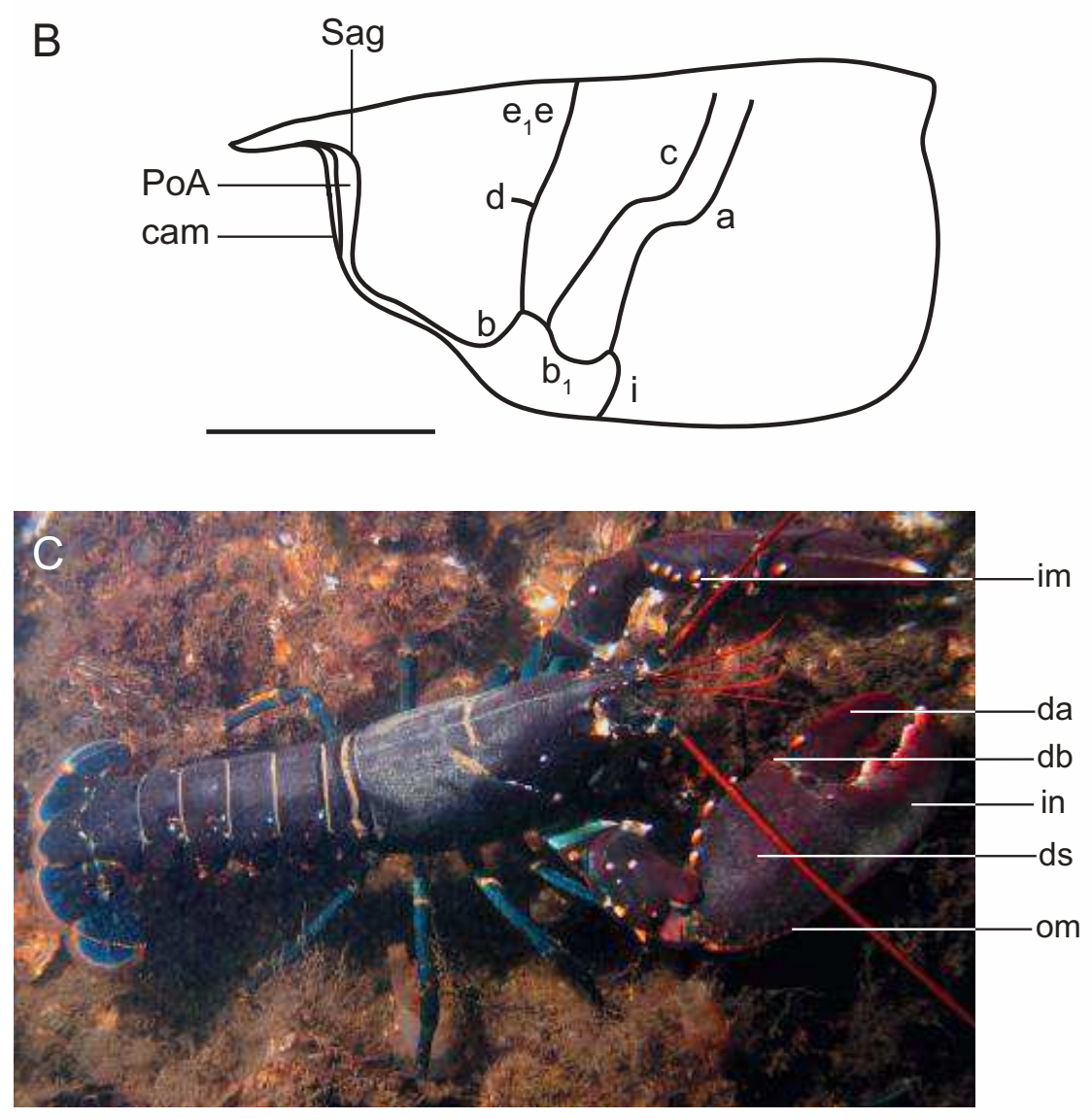

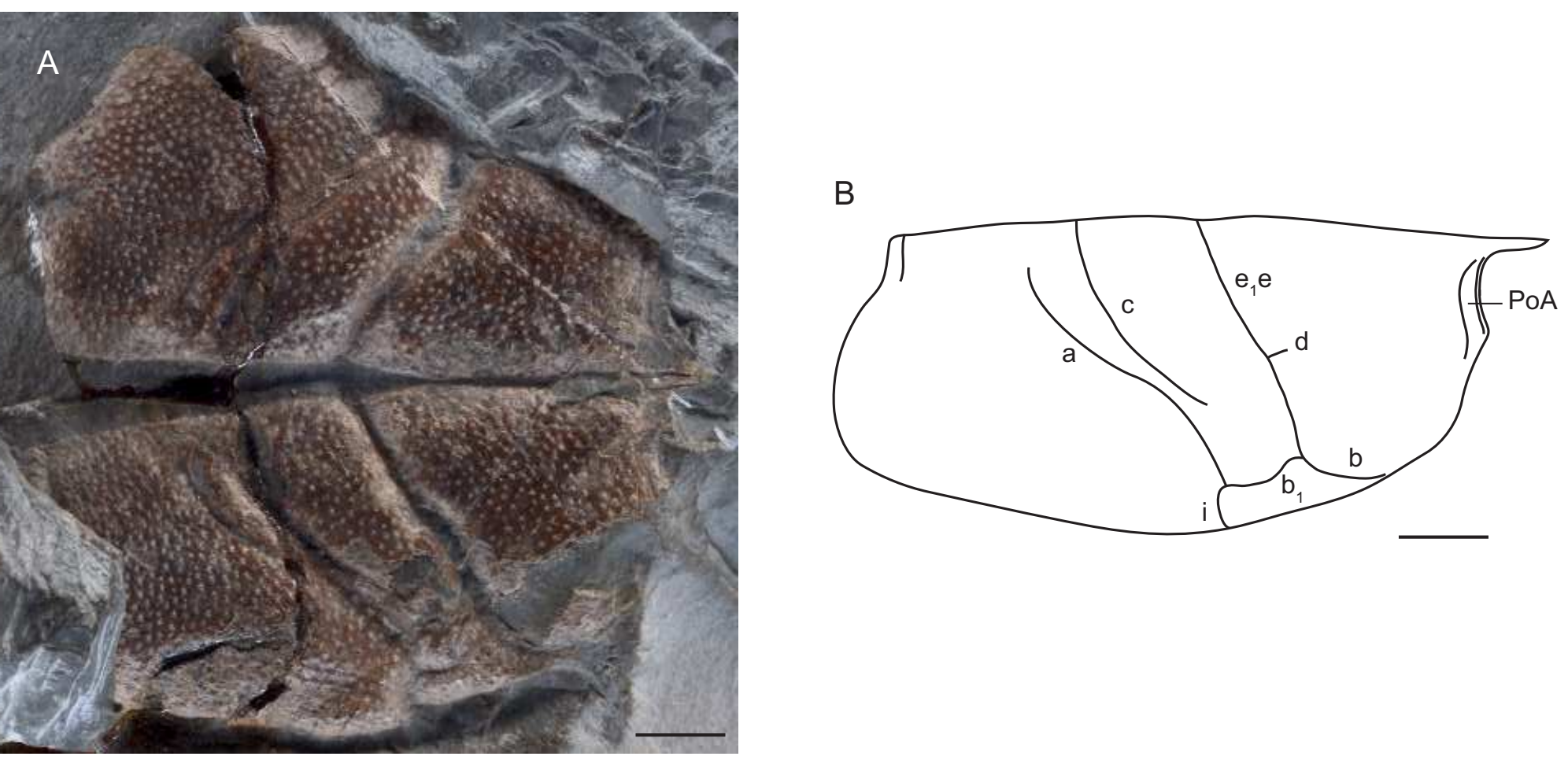

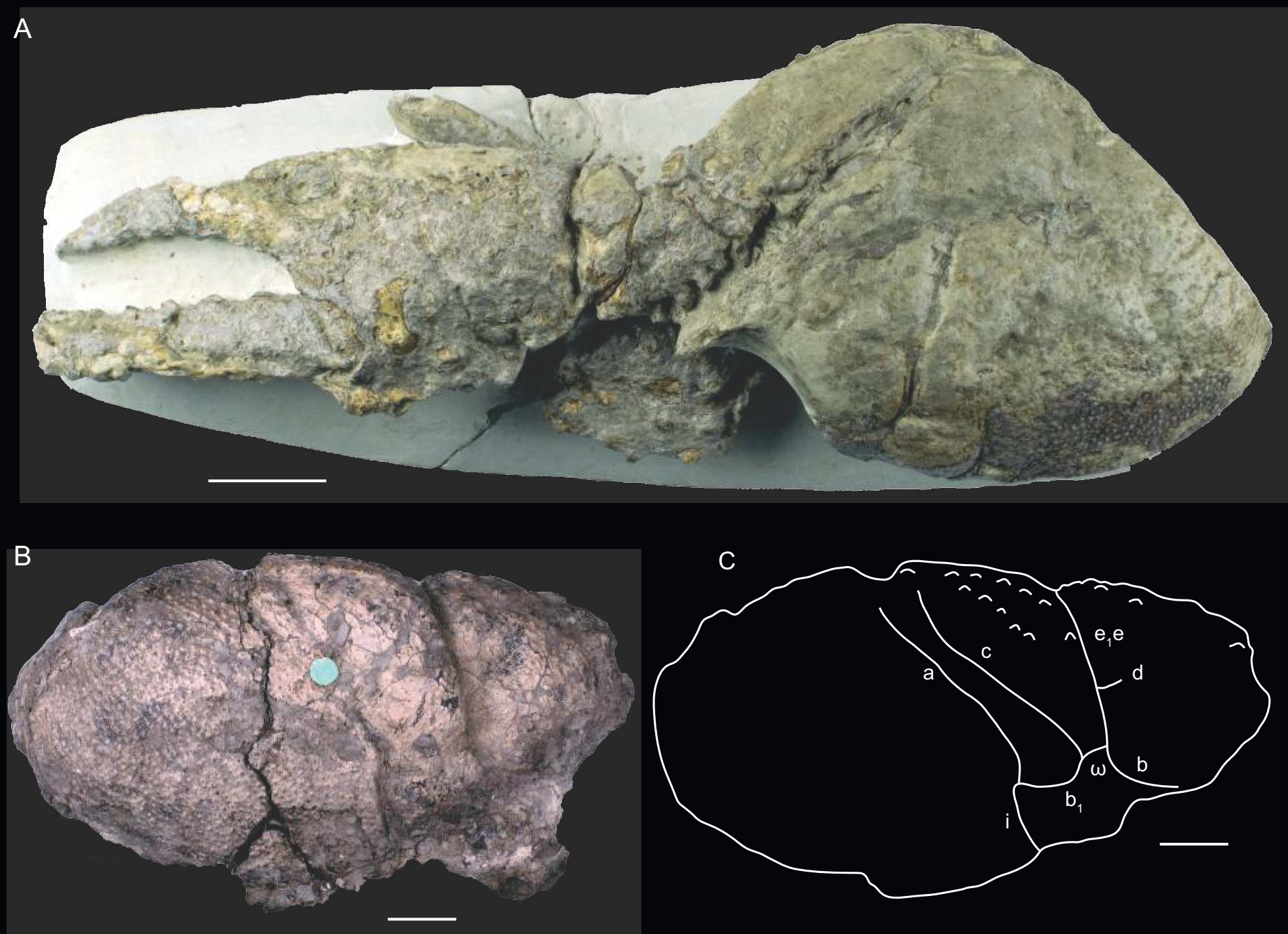

D
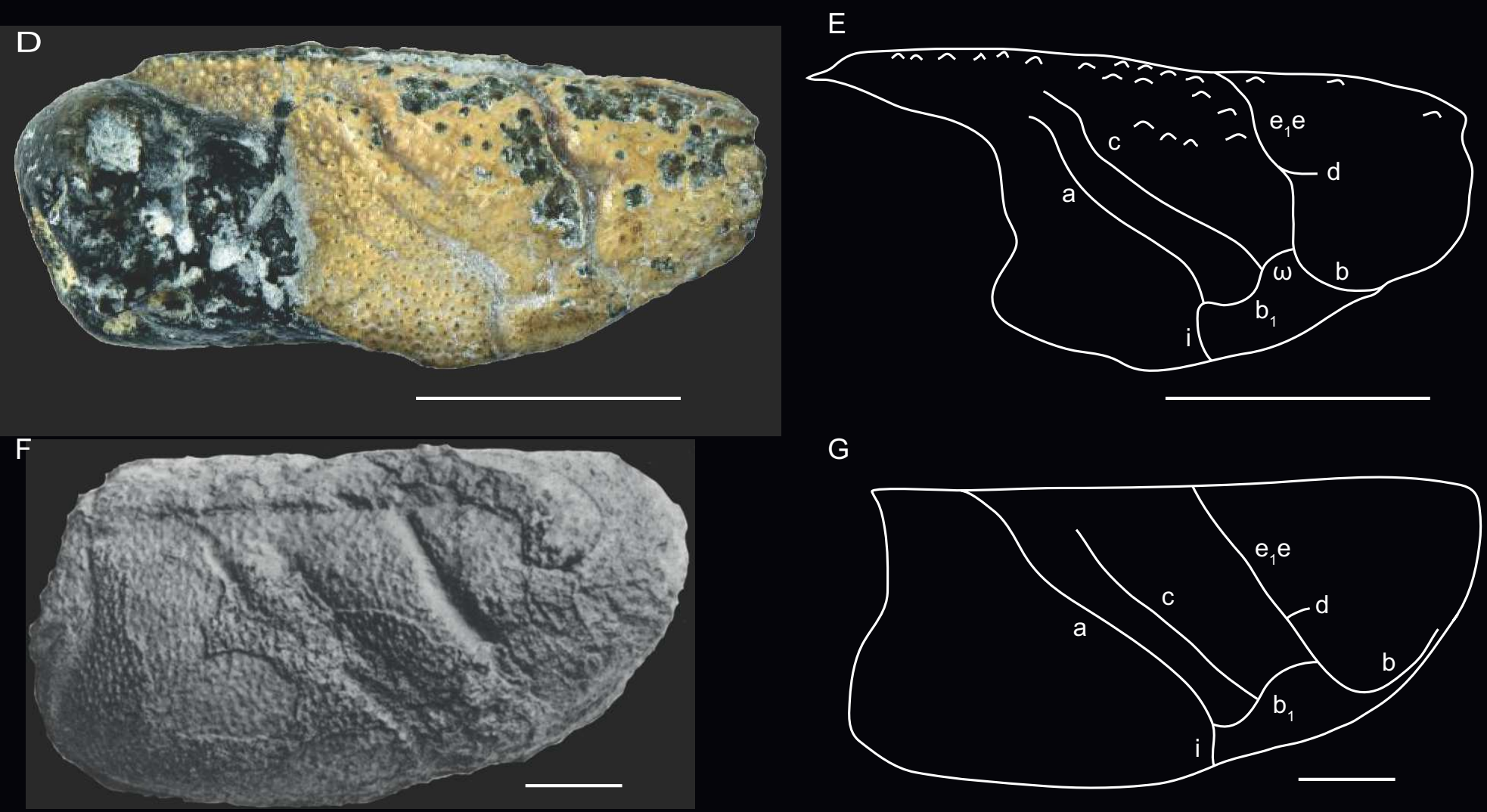

$\circ$

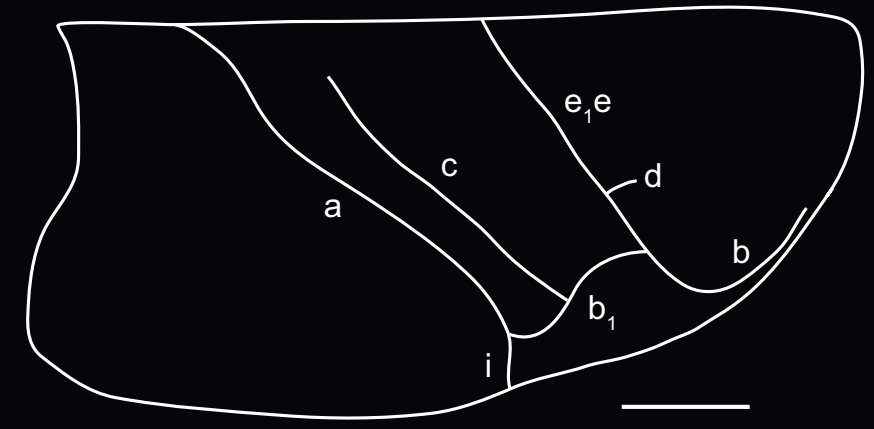



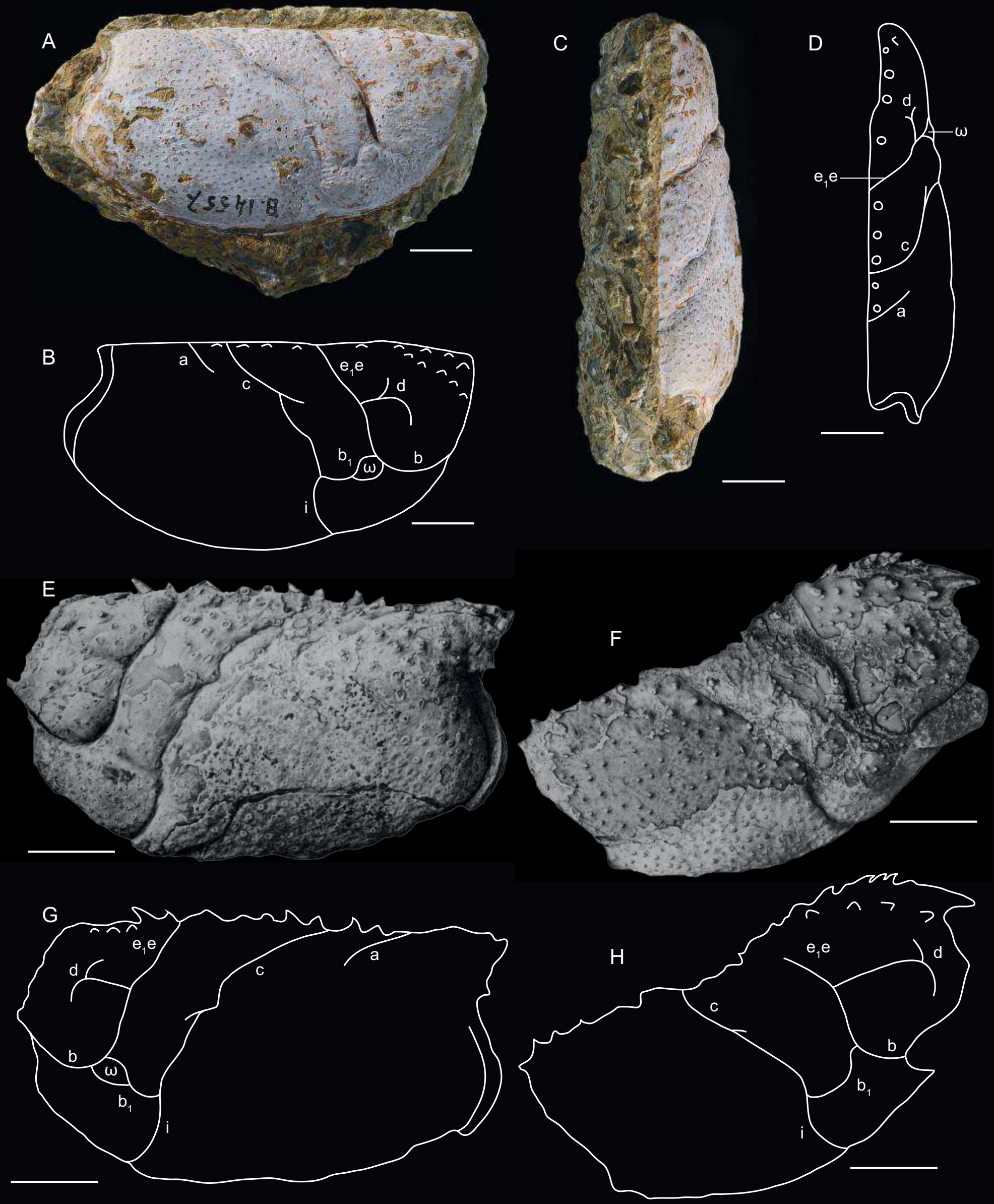
A

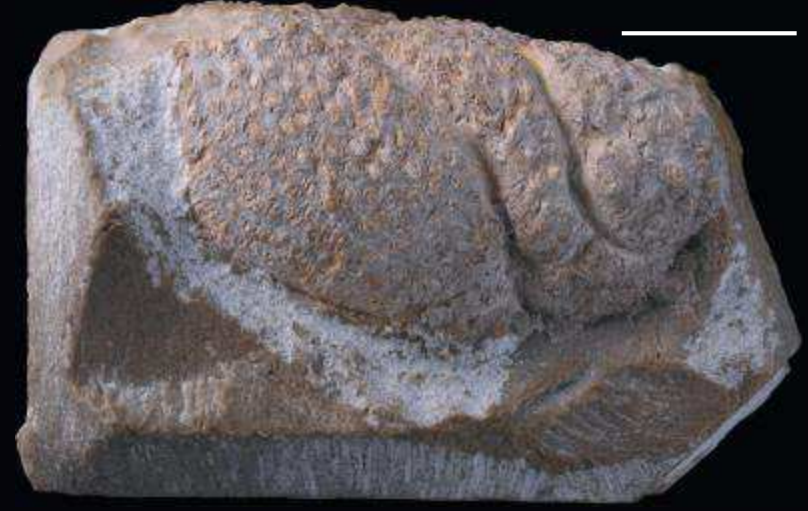

B

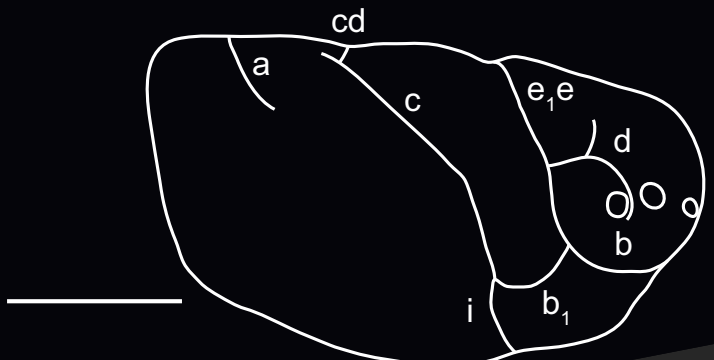

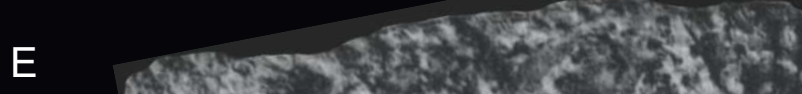

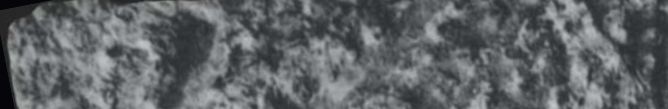

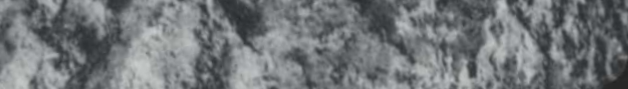

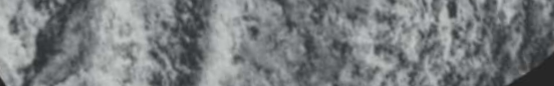

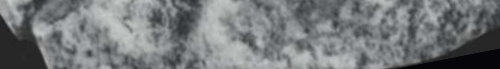
2intion

G

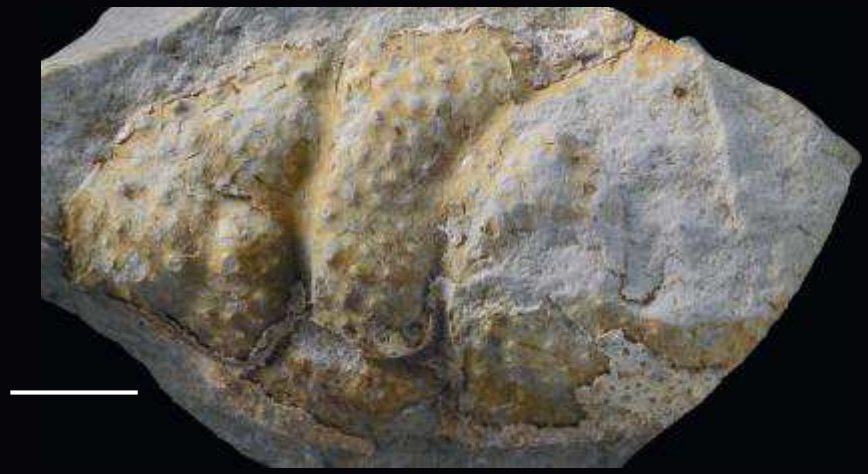

\section{I}
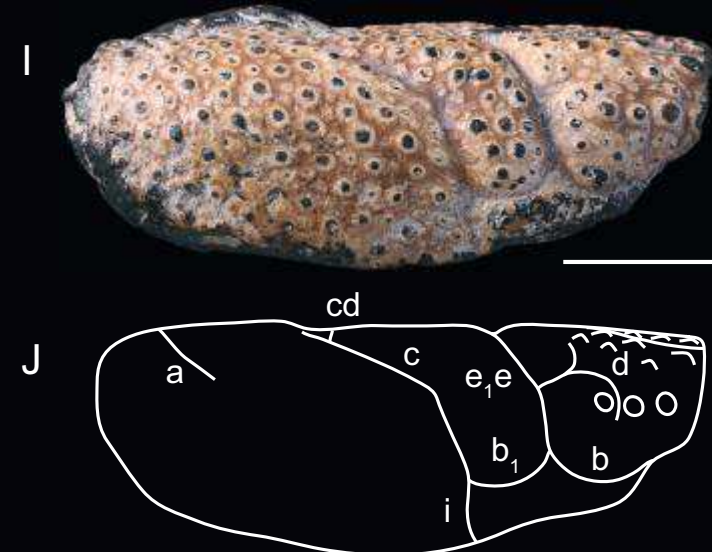
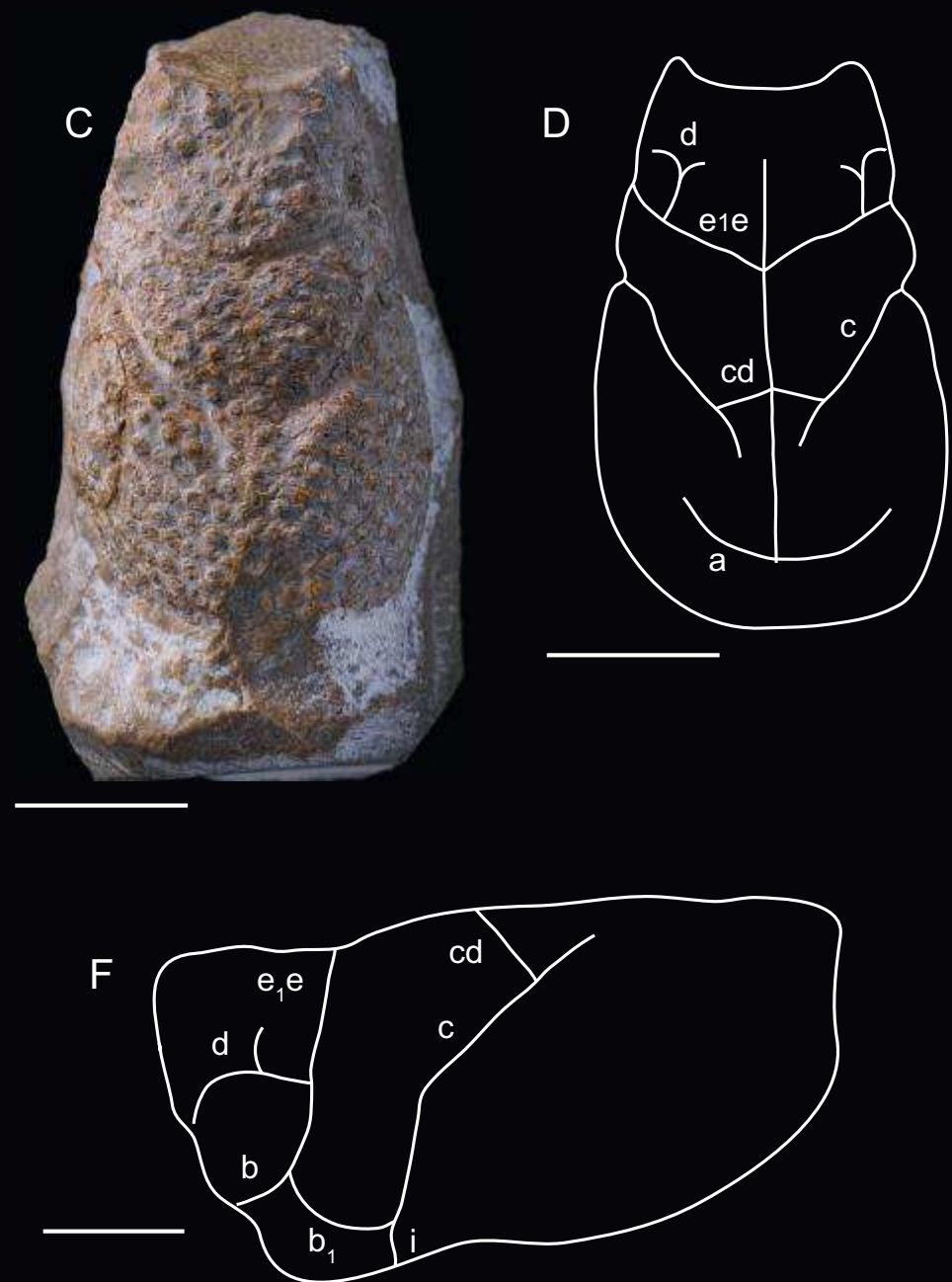

$\mathrm{H}$
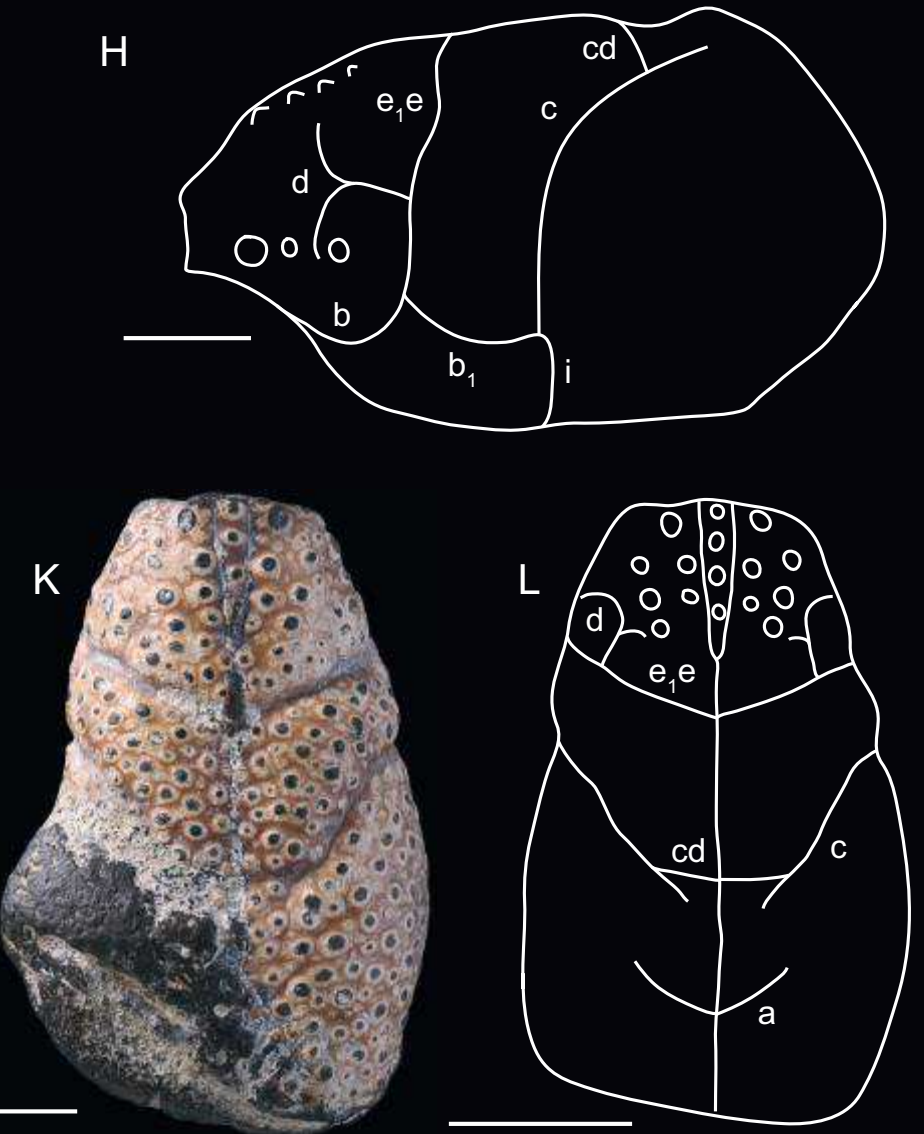

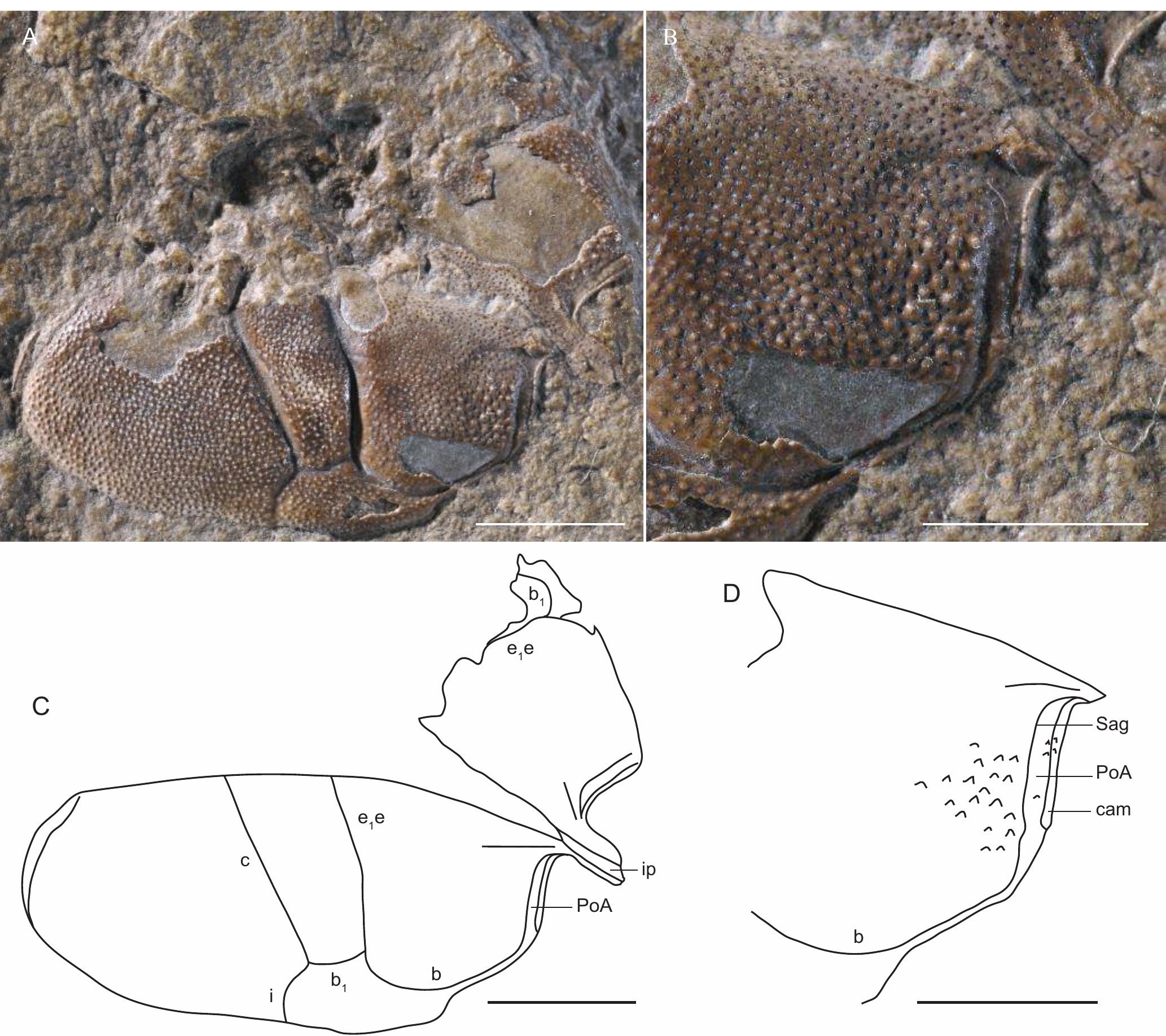